Suárez Padilla, J., Ramon Torres, J., Mora Serrano, B., Salvago Soto, L. y Chacón Mohedano, C. (2020): "La cronología fundacional de la Malaka fenicia: investigaciones en el solar del Rectorado de la Universidad de Málaga", Spal 29.1: 41-77. DOI: http://dx.doi.org/10.12795/spal.2020.i29.02

\title{
LA CRONOLOGÍA FUNDACIONAL DE LA MALAKA FENICIA: INVESTIGACIONES EN EL SOLAR DEL RECTORADO DE LA UNIVERSIDAD DE MÁLAGA
}

\section{THE FOUNDING CHRONOLOGY OF THE PHOENICIAN MALAKA: RESEARCH ON THE SITE OF THE RECTORY OF THE UNIVERSITY OF MÁLAGA}

\author{
JOSÉ SUÁREZ PADILLA \\ Responsable de la correspondencia \\ Departamento de Ciencias Históricas. Facultad de Filosofía y Letras \\ Campus de Teatinos. Universidad de Málaga, E-29010, Málaga \\ Profesor Doctor Interino (Área de Prehistoria) \\ Correo-e: josesuarez@uma.es (D) https://orcid.org/0000-0001-6795-8668 \\ ResearcherID: <https://publons.com/researcher/AAH-1833-2019> \\ JOAN RAMON TORRES \\ Consejo Insular de Ibiza. Departamento de Patrimonio Histórico. Av. España, 49. CP 07800 Ibiza \\ Técnico titular de Patrimonio Histórico \\ Correo-e: jramon@conselldeivissa.es (D) https://orcid.org/0000-0003-0646-4423 \\ ResearcherID: <https://publons.com/researcher/AAH-1763-2019> \\ BARTOLOMÉ MORA SERRANO \\ Departamento de Ciencias Históricas. Facultad de Filosofía y Letras. \\ Campus de Teatinos. Universidad de Málaga, E-29010, Málaga \\ Catedrático de Arqueología. \\ Correo-e: barmora@uma.es (D) https://orcid.org/0000-0002-0909-9225 \\ ResearcherID: <https://publons.com/researcher/D-9866-2014> \\ LETICIA SALVAGO SOTO \\ Proyectos MLK. Apartado de Correos 6094. 29080 Málaga \\ Correo-e: proyectos@mlk.es. D https://orcid.org/0000-0003-2011-0381 \\ ResearcherID: <https://publons.com/researcher/AAH-3841-2019> \\ CRISTINA CHACÓN MOHEDANO \\ Arqueóloga. Avda. Juan Sebastián Elcano № 182. 6 D. 29017 Málaga \\ Correo-e: arqueocris@gmail.com. (C https://orcid.org/0000-0002-5638-5312 \\ ResearcherID: <https://publons.com/researcher/AAG-9955-2019>
}

Resumen: Entre los años 1998 y 2002 se llevó a cabo una actividad arqueológica en el antiguo edificio de la Casa de Correos y Telégrafos de Málaga, como parte de los trabajos de rehabilitación necesarios para su uso como sede del Rectorado de la Universidad. El estudio sistemático de los materiales correspondientes a los niveles más profundos de la secuencia, atribuidos al periodo fenicio arcaico, permiten su datación en momentos anteriores a c 625 a.C., lo que los convierte, al día de hoy, en el contexto de mayor antigüedad de
Abstract: Between the years 1998 and 2002 an archaeological activity was carried out in the old building of the Correos (Post and Telegraph House) of Malaga, as part of the rehabilitation work necessary for its use as the seat of the Rector's Office of the University. The systematic study of the materials corresponding to the deepest levels of the sequence, attributed to the Phoenician archaic period, allows their dating before $c .625 \mathrm{BC}$, which makes them, to this day, the oldest known context associated to ancient Malaka. In addition to 
Malaka. Junto a este dato de valor cronológico destaca la entidad arquitectónica de algunas de las estructuras localizadas, inmediatas a la primera línea de costa de la época. El conjunto resulta de gran interés para estudiar la dinámica del poblamiento fenicio de la bahía de Málaga a partir de la fundación del asentamiento de la Rebanadilla, ubicado en el vecino estuario del río Guadalhorce, datado en la segunda mitad del siglo IX a.C.

Palabras clave: Colonización fenicia; cerámica fenicia; Hierro I; Malaka en el siglo VII a.C.

\section{PRESENTACIÓN}

Junto con otras sugestivas cuestiones, aún no resueltas, como es el mismo origen del topónimo (De Hoz 2010: 432, Martín Ruiz 2010: 78), la ciudad fenicia de Malaka, situada en la margen izquierda del río Guadalmedina, continúa arrastrando el problema de su cronología fundacional. Este aspecto resulta de particular interés, teniendo en cuenta que, hoy en día, la bahía de Málaga (concretamente el entorno de la desembocadura del río Guadalhorce) se configura como uno de los territorios más antiguos, junto con Huelva, de presencia fenicia arcaica en el sur de la península ibérica (fig. 1).

Algunas excavaciones arqueológicas desarrolladas en las últimas décadas en pleno casco histórico malagueño alcanzaron horizontes arcaicos en puntos clave como el palacio de Buenavista o la calle Císter, siendo objeto de publicación de sugerentes avances de resultados (Arancibia y Escalante 2006a y 2006b). No obstante, las secuencias mejores conocidas siguen siendo las procedentes del área del teatro romano (Gran-Aymerich 1991) y del colegio de San Agustín (Recio 1989), publicadas hace algunas décadas, y cuyos niveles más profundos no remontan más allá de la primera mitad del siglo VI a.C. (fig. 2).

Por este motivo, es obvio que la presentación del análisis, con una perspectiva moderna, de dos complejos vasculares hallados entre los años 1998-2002 en el antiguo edificio de Correos y Telégrafos, actual sede del Rectorado de la Universidad de Málaga, puede suplir, al menos provisionalmente, esta grave carencia e, incluso, convertirse en acicate para el estudio de otros contextos arqueológicos que permitan aproximarnos a la temporalidad, naturaleza y dinámica de la implantación colonial en la región. Este es el objetivo principal de esta aportación. this piece of chronological data, the site stands out because of the magnitude of its architecture, located immediately to the first coastline of the time. The assemblage is of great interest to study the dynamics of the Phoenician settlement of the bay of Malaga from the foundation of La Rebanadilla, located in the neighboring estuary of the Guadalhorce River, dated in the second half of the 9th century BC.

Key words: Phoenician colonization; Phoenician ceramics; Early Iron Age; Malaka in the 7th century BC

\section{LA EXCAVACIÓN ARQUEOLÓGICA EN EL EDIFICIO DE CORREOS DE MÁLAGA (1998-2002): EL PERIODO FENICIO ARCAICO}

Entre 1998 y 2002 se llevó a cabo una Actividad Arqueológica de Urgencia vinculada a los trabajos de Rehabilitación del antiguo Edificio de la Casa de Correos y Telégrafos, para su futuro uso como sede del Rectorado de la Universidad de Málaga (Chacón y Salvago 2005). Durante una primera fase (1998-1999) los trabajos se centraron en la excavación en extensión de la parcela. En años sucesivos se realizaron investigaciones puntuales en determinados sectores, en paralelo a la fase de control arqueológico de las obras (2000-2002) (fig. 3).

El solar investigado tenía una superficie de $1461 \mathrm{~m}^{2}$, si bien en más de la tercera parte del sitio emergía directamente el sustrato geológico. Esta circunstancia responde, en particular, a las importantes afecciones que sufrió este sector de la ciudad a partir de finales del siglo XIX, junto a la destrucción del subsuelo que supuso la propia construcción del edificio público. A pesar de estas limitaciones, la actuación arqueológica permitió documentar restos constructivos y deposicionales correspondientes a una secuencia estratigráfica en la cual están representados, de forma desigual, los periodos fenicio arcaico, romano, medieval, moderno y contemporáneo (Chacón y Salvago 2005: 20-25). Para los objetivos de este artículo, nos centraremos en una descripción detallada de la secuencia estratigráfica correspondiente al momento más antiguo (fig. 4).

En términos generales, se trata de una serie de retazos de estructuras en positivo junto a algunas fosas y estratos de relleno, concentrados en un espacio de unos $20 \mathrm{~m}^{2}$ ubicado en la mitad occidental de la parcela. 


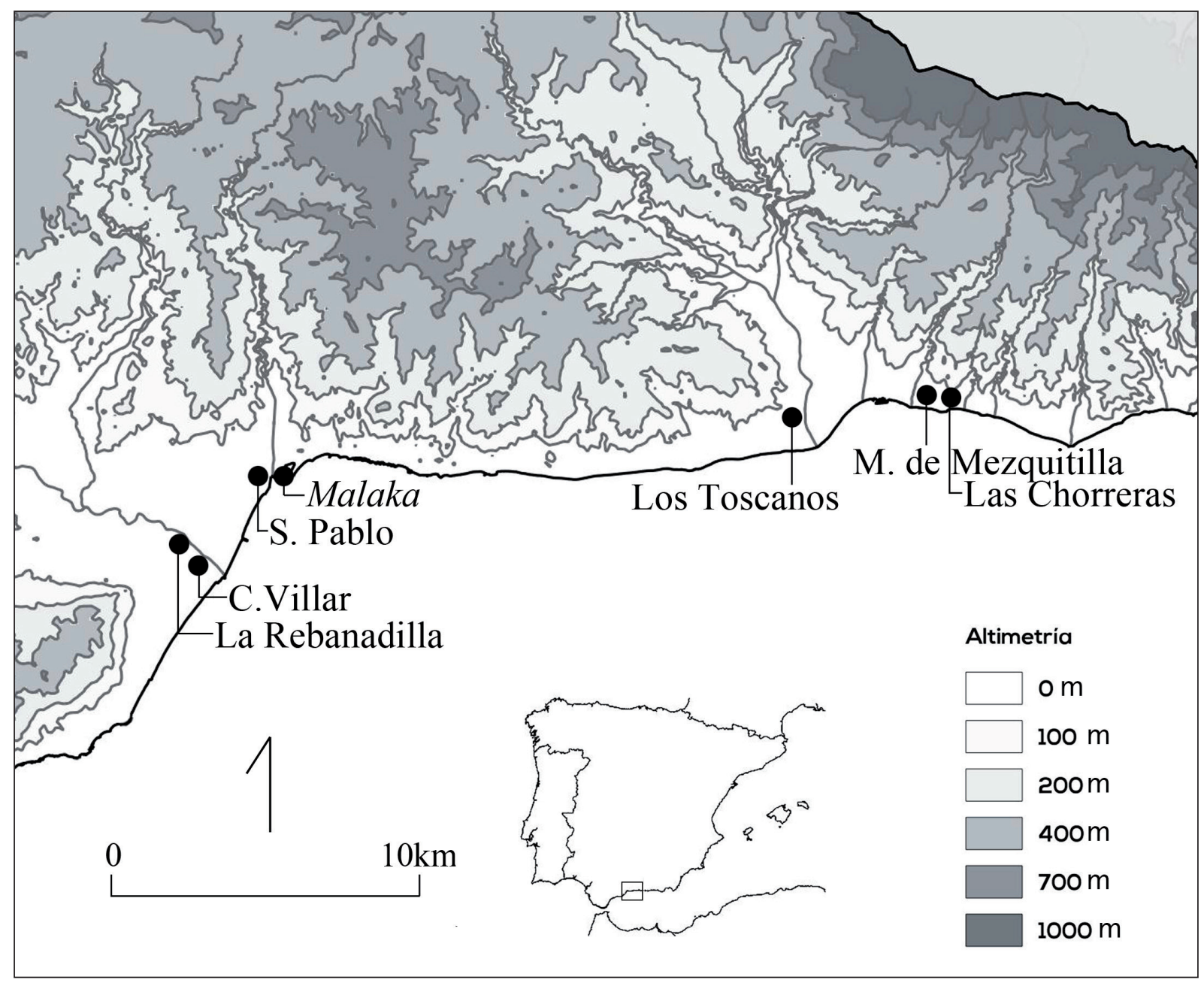

Figura 1. Principales asentamientos fenicios e indígenas en el litoral centro-oriental de Málaga (finales del siglo IX-VII a.C.).

Este ámbito se denominó "sector del muro fenicio". Es necesario señalar que estos restos se encontraban, por lo general, en mal estado de conservación, como resultado de importantes afecciones posteriores entre las que destacan las resultantes de la construcción sobre los mismos de la factoría de salazones de época romana. En particular, esta circunstancia ha limitado en extremo la interpretación de la naturaleza de los restos correspondientes al periodo en estudio (fig. 5).

Previamente a las primeras construcciones del periodo fenicio, la paleotopografía de este sector meridional de la actual colina de la Alcazaba se caracterizó por presentar una ladera de pendiente acusada, que entraba en contacto con el mar.

Los retazos de muros conservados presentan orientación tanto en sentido norte-sur como este-oeste, adaptándose aparentemente a las irregularidades de la topografía del frente marítimo. Concretamente, los denominados como MR02 y MR07 presentan un aparejo de mampuestos de rocas locales careadas (bloques de pizarra y ocasionalmente areniscas), ligadas con barro. Las piedras de MR02 se adaptan al perfil de la roca natural (UE17), posiblemente regularizada de forma artificial (FS16). Al extremo de MR02 se adosa transversalmente un muro denominado MR01. Es una sólida estructura con $80 \mathrm{~cm}$ de ancho, en cuya construcción se emplearon mampuestos pizarrosos, algo regularizados al exterior, dispuestos en hiladas con ripios y ligadas con barro. Para su construcción se llevó a cabo un recorte artificial del frente de roca, que propició espacio suficiente para facilitar la fábrica de su cara interior (FS11). El muro arranca de una hilada a modo de zarpa, que sobresale unos centímetros del resto (UE10) y que apoya directamente sobre el nivel geológico base, a una cota de 2,78 m s.n.m. Este 


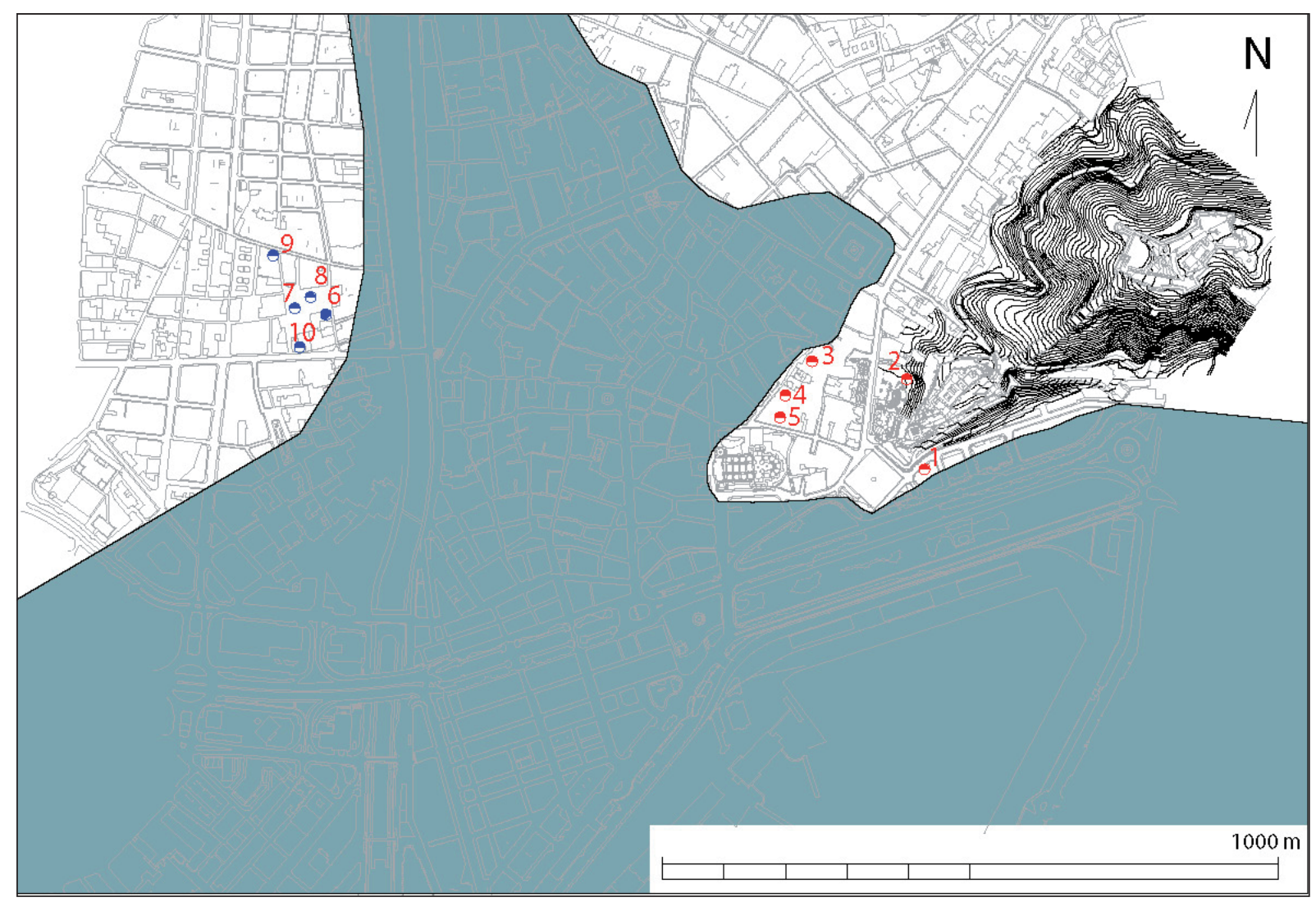

Figura 2. La intervención arqueológica del edificio del Rectorado de la Universidad de Málaga, en el contexto de las principales intervenciones arqueológicas con hallazgos fenicios arcaicos y autóctonos en el marco del paleoestuario del río Guadalmedina (siglos VIII-VI a.C.). 1. Rectorado de la Universidad de Málaga; 2. Ladera de la colina de la Alcazaba-Teatro romano; 3. Museo Picasso-Palacio de Buenavista; 4. Calle San Agustín; 5. Calle Císter-San Agustín; 6. Plaza de San Pablo esquina calle Jara; 7. Entorno de la Plaza de San Pablo; 8. Plaza de San Pablo; 9. Calle San Pablo 19; 10. Calle Tiro esquina a Zamorano.

paramento conserva una altura que varía desde los 1,70 $\mathrm{m}$, a los 2,60 m, alcanzando una cota máxima de 5,43 m s.n.m. Esta diferencia de altura de cerca de un metro es resultante de la afección supuesta por la construcción en época romana de la denominada Pileta IX, que lo destruyó en gran parte. (figs. 6 y 7).

Los grosores de $80 \mathrm{~cm}$ empleados en esta construcción (MR01) remiten al empleo del "codo fenicio" de $52 \mathrm{~cm}$ Esta metrología - 1,5 codos en nuestro caso - es frecuente en la arquitectura de tradición oriental (Barresi 2007: 19). Buenos ejemplos de ello son muros empleados como sistema de contención de tierras para posibilitar la disposición de viviendas escalonadas en las laderas de promontorios, caso de las construcciones del periodo fenicio arcaico (siglo VIII a.C.) del Teatro Cómico de Cádiz (Gener et al. 2014: 22, 35-36), en Chorreras (Martín y Recio 2012: 209, 211), así como en Toscanos (Arnold y Marzoli 2009: 444). No obstante, esta metrología convive en ocasiones con la del empleo del codo de 45-46 cm (Barresi 2007: 22, Montanero 2014: 78), identificada en el propio yacimiento de Malaka, aunque para fechas algo posteriores. Es el caso de algunas estructuras localizadas en las excavaciones del Museo Picasso, así como en el santuario excavado en la cercana calle del Císter (Arancibia y Mora 2018: 357359), luego amortizado por las primeras murallas de la ciudad.

El espacio resultante entre la fosa FS11, practicada para facilitar la construcción de MR01, y la propia cara interior del muro, se rellenó con diversos aportes terrígenos realizados desde el exterior (UEs 09, 08 y 06). El estrato más profundo es UE09, que presenta una acusada pendiente adaptándose al corte practicado en la ladera y que cubre la zarpa (UE10) del muro, apoyando contra él. Este nivel de relleno, de matriz de naturaleza 


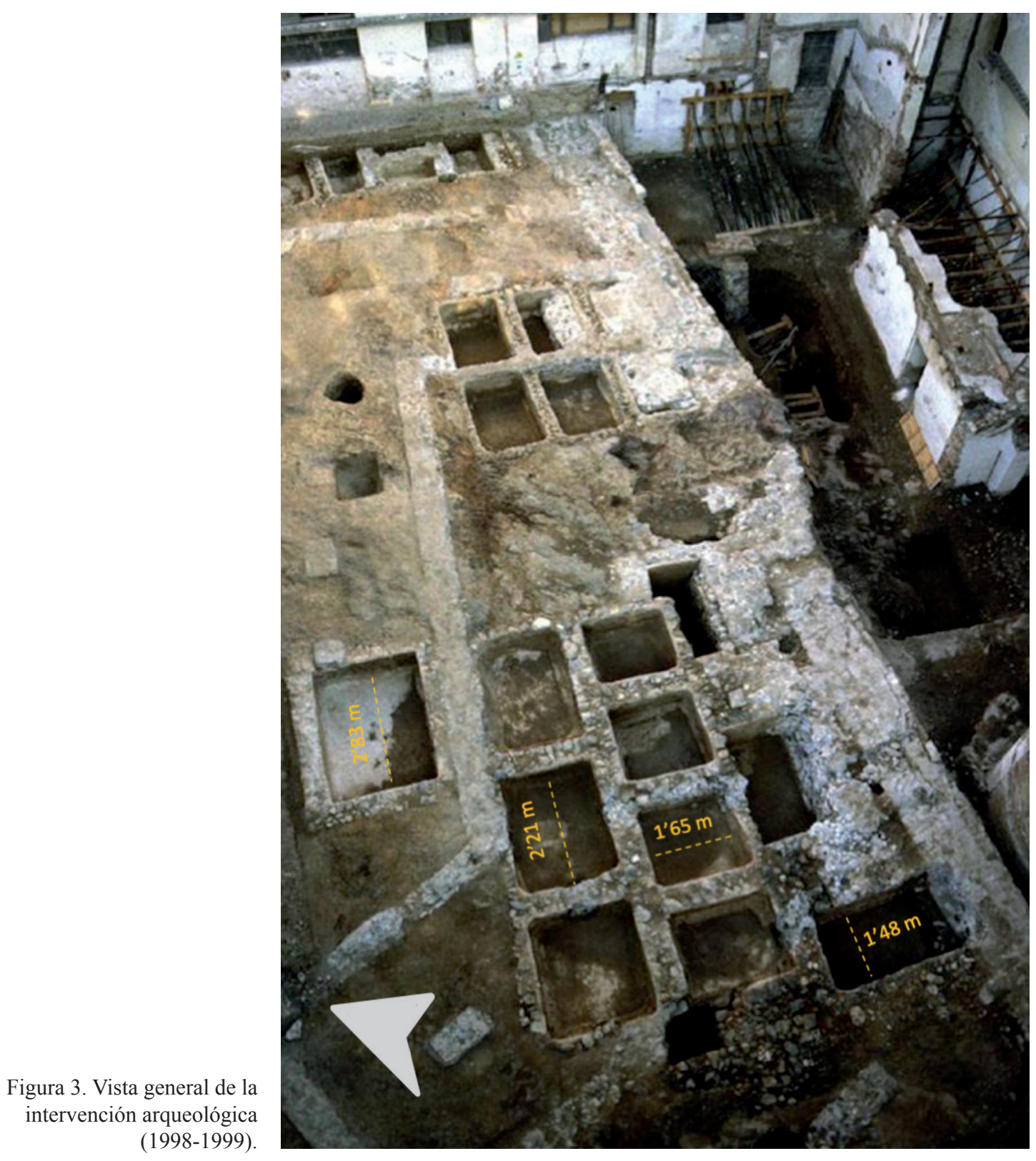

arcillosa y color marrón oscuro, semicompacto, parece ser resultado de un vertido con inclusiones propias de materiales de desecho de actividades domésticas. Contiene una presencia significativa de pequeños nódulos de carbón, junto a un número elevado de fragmentos cerámicos, con escasos indicios de rodamiento, así como restos de malacofauna, con un número mínimo de 18 individuos, que corresponden a un total de 10 especies de moluscos marinos, entre bivalvos y gasterópodos. Todo apunta a que se trata de materiales relacionados con actividades domésticas (fig. 8).
Cabe señalar que se dispone de una datación absoluta para este estrato, obtenida a partir de una muestra de car-

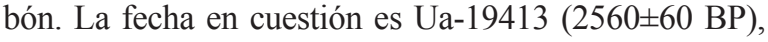
que, calibrada y con un $95,4 \%$ de probabilidad, aporta una horquilla cronológica que resulta excesivamente amplia, entre el 832 y el 488 cal BC, al caer de pleno en la conocida como "meseta de Hallstatt", que corresponde a los primeros siglos de la Edad del Hierro. Es por ello por lo que esta fecha radiocarbónica no resulta una aportación determinante para ajustar con precisión la cronología de este estrato, aunque sí es coherente con 


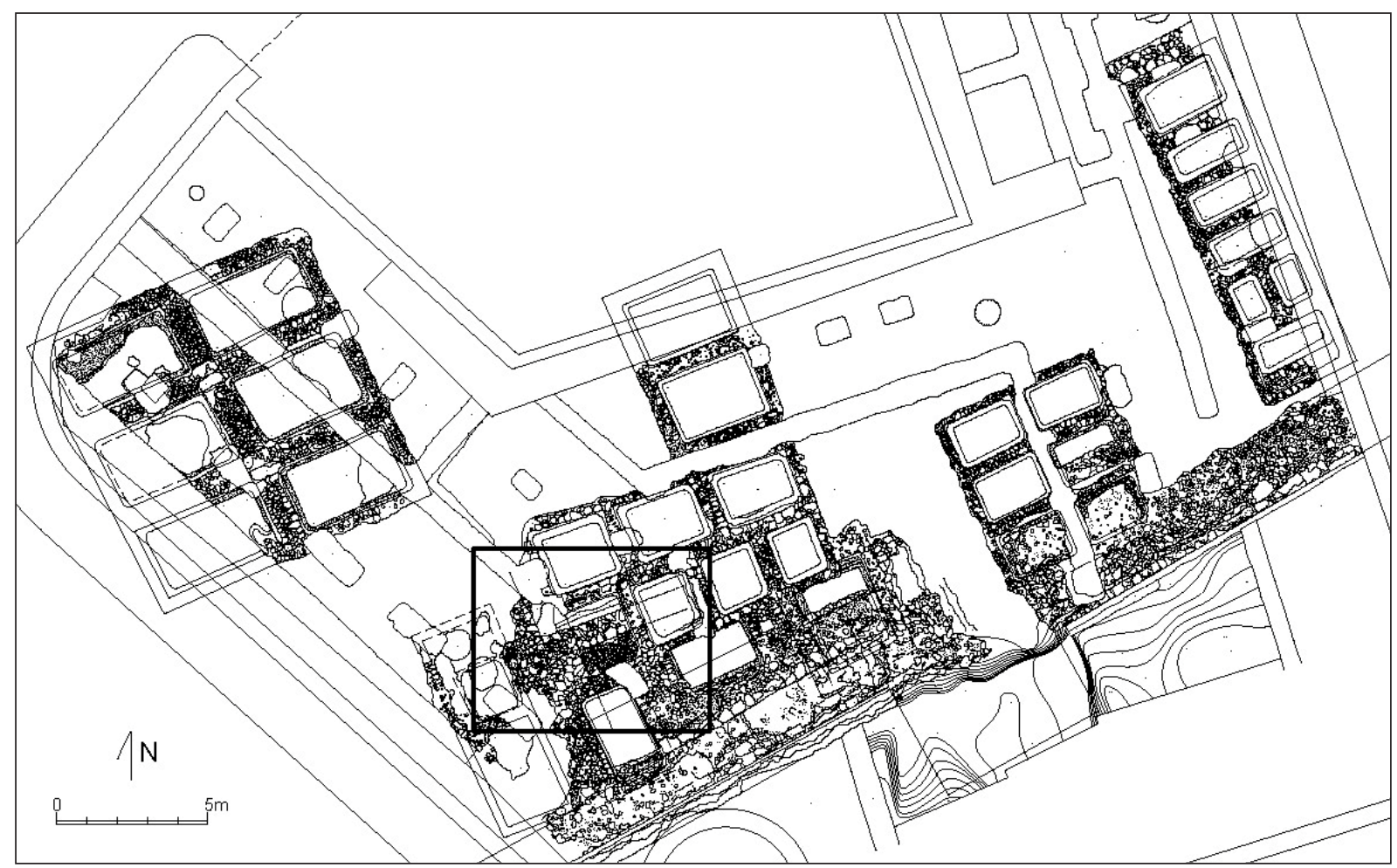

Figura 4. Planta general de las excavaciones del edificio del Rectorado de la Universidad de Málaga (antiguo Correos).

la propuesta de datación convencional resultante del estudio de la cerámica, como se verá más adelante (fig. 9).

UE08 es un estrato que cubre a UE09 y se apoya a su vez en MR01. Presenta matriz algo más arcillosa y compacta, color marrón-amarillento, sin apenas carbones y fragmentos cerámicos, de naturaleza semejante a los subyacentes. El estrato superpuesto a UE08 es UE06, que presenta escasa potencia, una matriz semejante a UE08 y práctica ausencia de material arqueológico. Sobre este último se forma UE03, el relleno superior documentado en la FS11. No presentaba material arqueológico.

Al exterior de MR01 se documentó parcialmente la existencia de un nivel con abundantes piedras (UE14). Tanto estos mampuestos, como el propio muro fueron definitivamente amortizados por un suelo (SL12) localizado al ser destruido parcialmente el suelo de la Pileta IX, y cuya cronología es incierta. A MR01 se adosó otro muro en sentido transversal y paralelo a MR02, denominado MR07, con desarrollo longitudinal en dirección al mar. De este paramento apenas se pudo identificar algo menos de medio metro, al presentarse muy afectado por las construcciones romanas. Pudo cumplir la función de regularización del frente oriental del espigón rocoso que avanzaba hacia el litoral. El espacio resultante entre la roca natural (UE17), previamente recortada (FS16), y MR03 se macizó con piedras (UE04).

Posiblemente a un momento de destrucción de estas estructuras corresponda el estrato UE05, interpretado, a priori, como posible derrumbe situado al exterior de MR07. El espacio conformado por MR03 y las UEs 04 y 05 coincidía con la implantación de un pilar de la cimentación del nuevo edificio del Rectorado, por lo que fue parcialmente destruido y no pudo ser investigado en profundidad.

Con los restos conservados y documentados no deja de resultar arriesgado interpretar con garantías la naturaleza de esta secuencia estratigráfica. Algunos aspectos a destacar serían la entidad de paramentos como MR01, que presenta una orientación adaptada a las curvas de nivel y a la propia línea de costa. Esta última se mantuvo sin grandes variaciones en este sector de la ciudad hasta finales del siglo XIX (figs. 10 y 11), circunstancia que contrasta con otros ámbitos sujetos a la deposición de aluviones procedentes del río Guadalmedina (Mora y Arancibia 2010: 825-826). Es por ello, por lo que en este mismo solar se conservan retazos de lienzos defensivos de época islámica e incluso moderna, que discurren con una orientación semejante a la de este potente muro fenicio. 


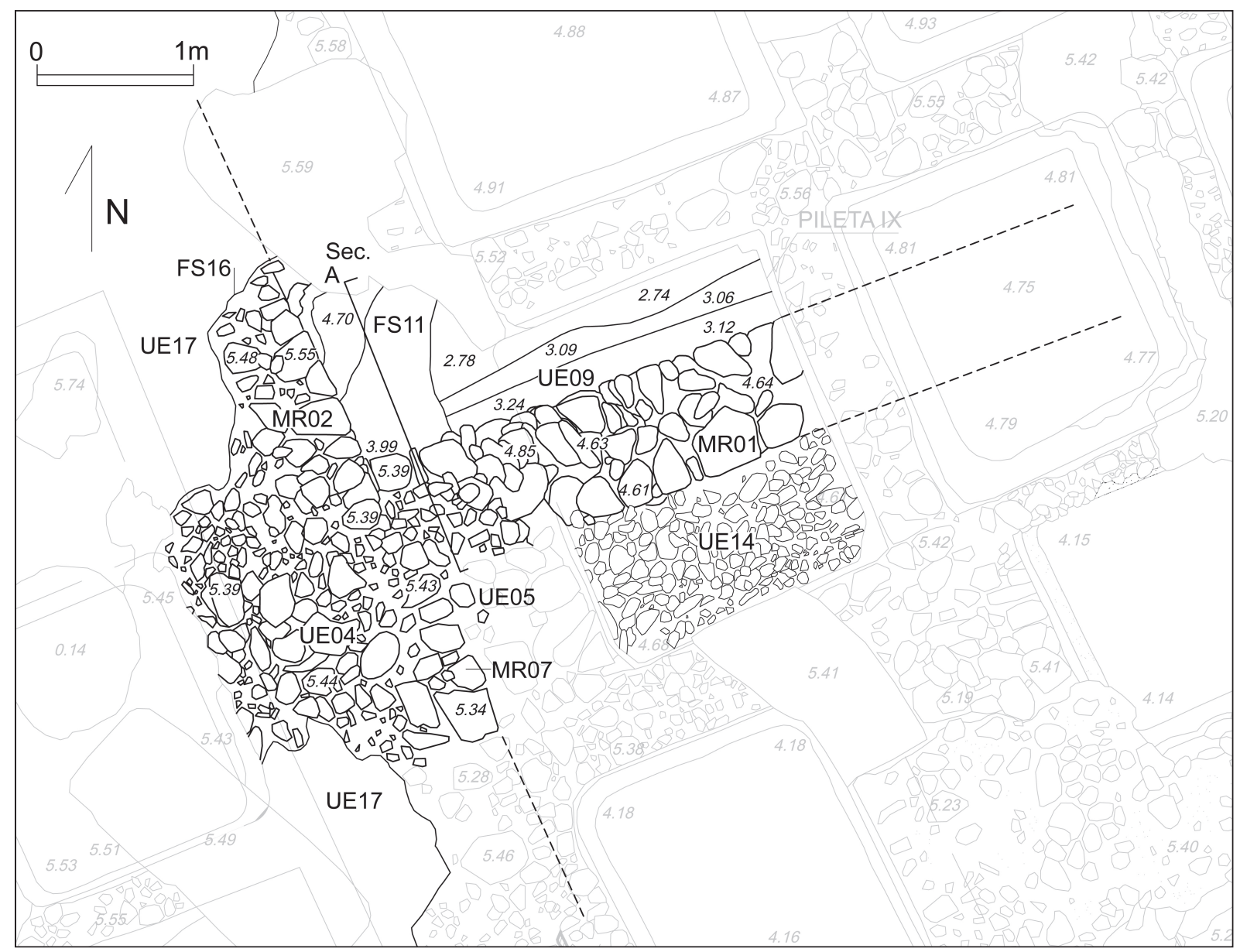

Figura 5. Planta de detallle de las estructuras y depósitos correspondientes al período fenicio.

Todo indica la existencia de construcciones del primer asentamiento de Malaka en primera línea marítima, que se habrían adaptado, con ciertas modificaciones, a la topografía natural preexistente. De hecho, una de las posibles funciones de estas potentes construcciones pudo ser la de acondicionamiento de esta acusada ladera para generar superficies escalonadas sobre las mismas. Si esto fuese así, debemos suponer que buena parte de la ladera sur de la colina de la Alcazaba pudo presentar un hábitat de aspecto "típicamente fenicio", si nos atenemos a la tópica lectura urbanística que le atribuye Estrabón (III. 4. 2) para diferenciarla de la griega Mainake. Este sistema constructivo, empleado allí donde la topografía lo exige, ha sido bien documentado en yacimientos fenicios arcaicos cercanos, como Chorreras (Vélez-Málaga) (Martín y Recio 2012: 209).

En este sentido, las remociones llevadas a cabo en la ladera suroriental de la colina de la Alcazaba a inicios del siglo XX, descritos por Rodríguez de Berlanga
(Berlanga 2001: 145-153), depararon interesantes descubrimientos arqueológicos que permitieron plantear en su momento la ubicación en este punto de una parte de la ciudad antigua (Rodríguez de Berlanga 2001: 217-219). La localización años más tarde, en este mismo sector, de una domus urbana (Serrano y Rodríguez 2009: 49, nota 9), identifica para época imperial romana al menos una terraza artificial situada a una cota de 6,60 m s.n.m.

Es cierto que las recientes excavaciones en el casco urbano antiguo de la ciudad, concretamente en los solares del Museo Picasso y calle Císter, han venido a confirmar la compleja topografía antigua de la ciudad fenicio-púnica, que también se extiende al sector del río Guadalmedina continuando el antiguo poblamiento identificado en el entorno de la iglesia de San Pablo, en el malagueño barrio de la Trinidad (Mora y Arancibia 2010: 821-822). Pero los hallazgos con contexto arqueológico que comentamos de Correos Viejo insisten también en la ocupación urbana de la ladera sur de 


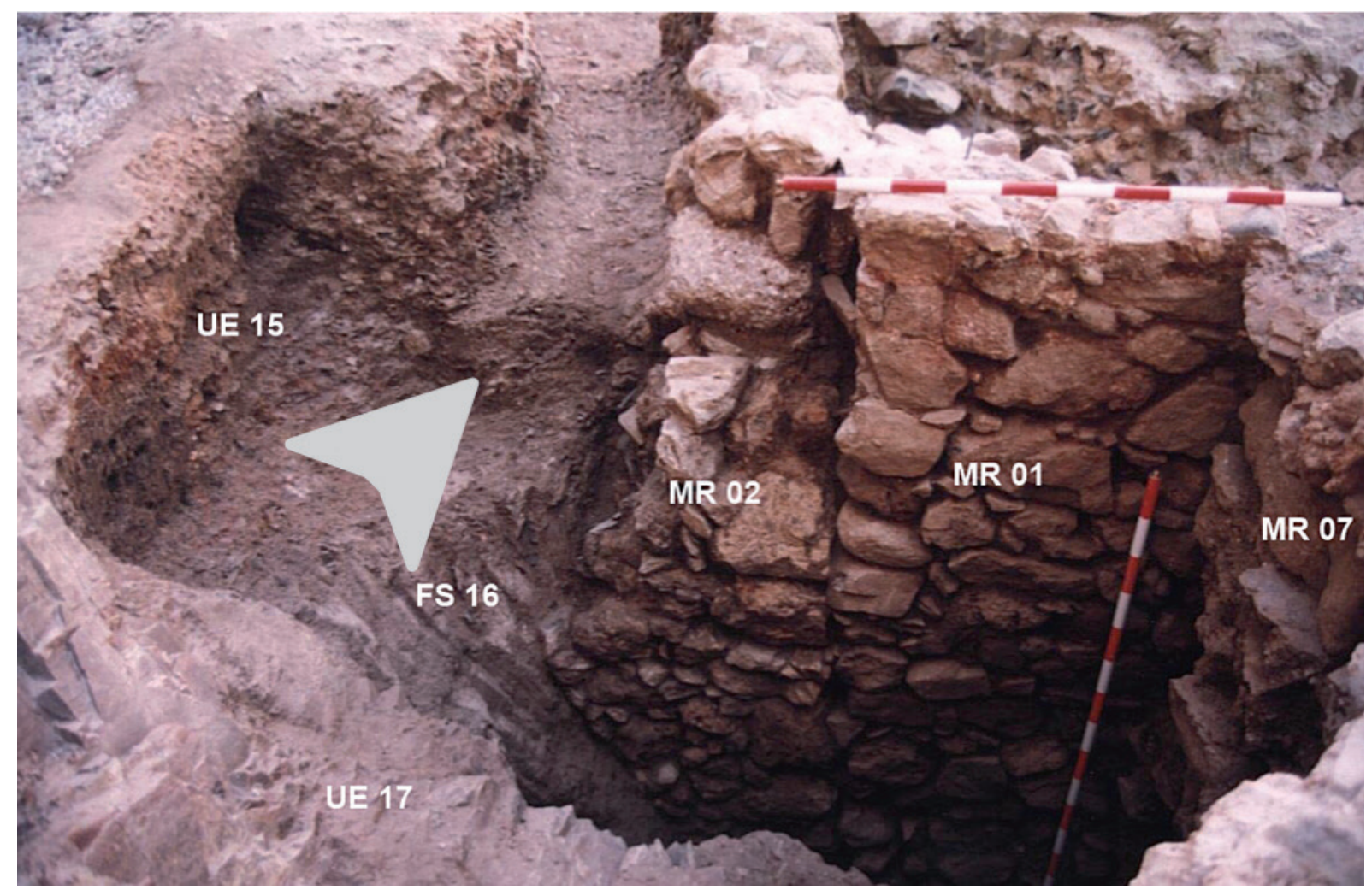

Figura 6. Detalle de la conexión entre los paramentos MR01 y MR02.

la Alcazaba, ampliando el límite de la ciudad hacia el este y dando un mayor sentido a la ubicación de la necrópolis fenicio-púnica de los Campos Elíseos, en uso al menos desde el siglo VI a.C. (Martín 2010: 82, Mora y Arancibia 2010: 820, 827).

\section{LOS MATERIALES ARQUEOLÓGICOS PROCEDENTES DE LAS UES 08 Y 09}

La cerámica contenida en los estratos objetos de estudio se caracteriza, en general, por su buen estado de conservación y por presentar escasos indicios de rodamiento. Se concentran en dos UEs: la UE08 (fig. 12) y la UE09 (figs. 13, 14 y 15). Se presenta una selección de imágenes de piezas representativas del conjunto (fig. 16).

\subsection{La cerámica a torno}

Los tipos que se estudian a continuación, de distribución por lo general amplia, han sido ya debatidos en múltiples ocasiones y ello exime ahora de dar listas exhaustivas de paralelos, que se pueden hallar en diferentes publicaciones harto conocidas. Sin embargo, para la mayoría de ellos, subyacen aún no pocas dudas que afectan de modo particular a su ajuste cronológico.

\subsection{1. Ánforas de almacenaje y transporte}

El conjunto de este tipo de contenedores se enmarca tanto tipológicamente como por sus pastas entre las producciones propias del ámbito fenicio occidental, a las que se suma una pieza de importación de taller ático.

\subsubsection{1. Ánforas fenicias de fabricación occidental.}

Los recipientes de almacenaje occidentales están representados por dos bordes de la UE08 (fig. 12.1 y 12.2) y otros dos de la UE09 (fig. 13.1 y 13.2) que, en todos los casos, se atribuyen al T-10121 (Ramon 1995: 30-231, fig. 109, 196-198), igual que las carenas de la UE08 (fig. 12.3) y de la UE09 (fig. 13.4 a 13.7). Los bordes primeros (fig. 12.1 y 12.2), son más altos (especialmente el núm. 1) y carecen de otros detalles especiales, 


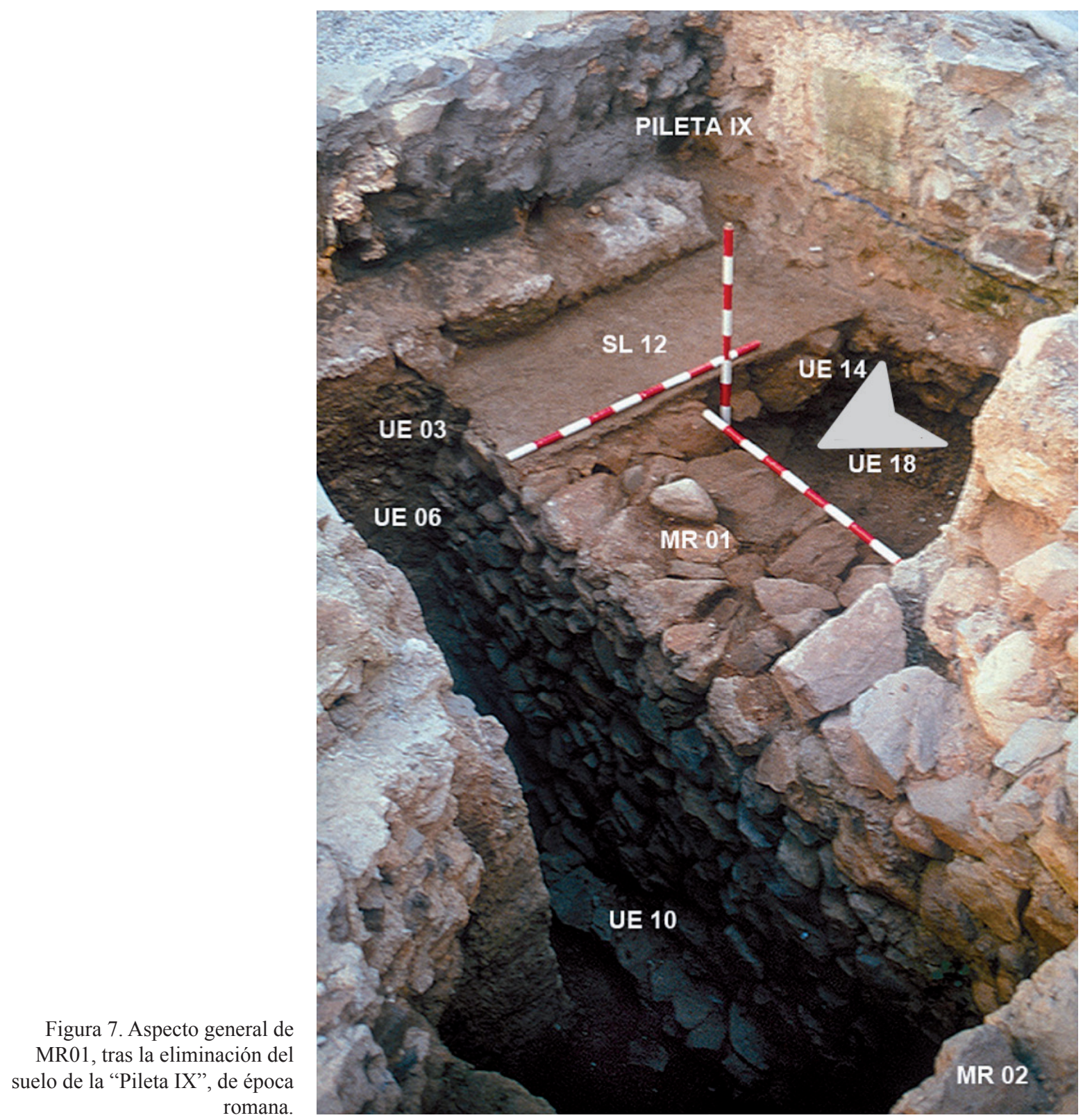

mientras que los de UE09 (figs. 13.1 y 13.2) son más bajos y de sección subtriangular; entre ellos solo el núm. 2 ofrece la típica incisión en la base externa, mientras que el núm. 1 es marcadamente oblicuo-exvasado.

No se aprecian, pues, aspectos que claramente apunten a tipos de ánforas más tardíos, como son las T-10211 (Ramon 1995: 231-232, fig. 110 y 198), sucesoras de las T-10121. Tras la publicación exhaustiva de las excavaciones de la Universidad de Alicante en el asentamiento fenicio de La Fonteta, cuya aportación al conocimiento de los complejos vasculares del siglo VII a.C. actualmente resulta clave, se comprueba que todos los tipos de borde que conforman el corto, pero significativo, repertorio anfórico de Correos encuentran similares estrictos en el numeroso material de la fase II de La Fonteta (González 2011a: 291-295, fig. 3-18), con una cronología ante quem cifrada en 650-640 a.C.

\subsubsection{2. Ánfora griega}

Se han localizado tres fragmentos (fig. 15.40 a 15.42) correspondientes a dos galbos y un trozo de cuello 


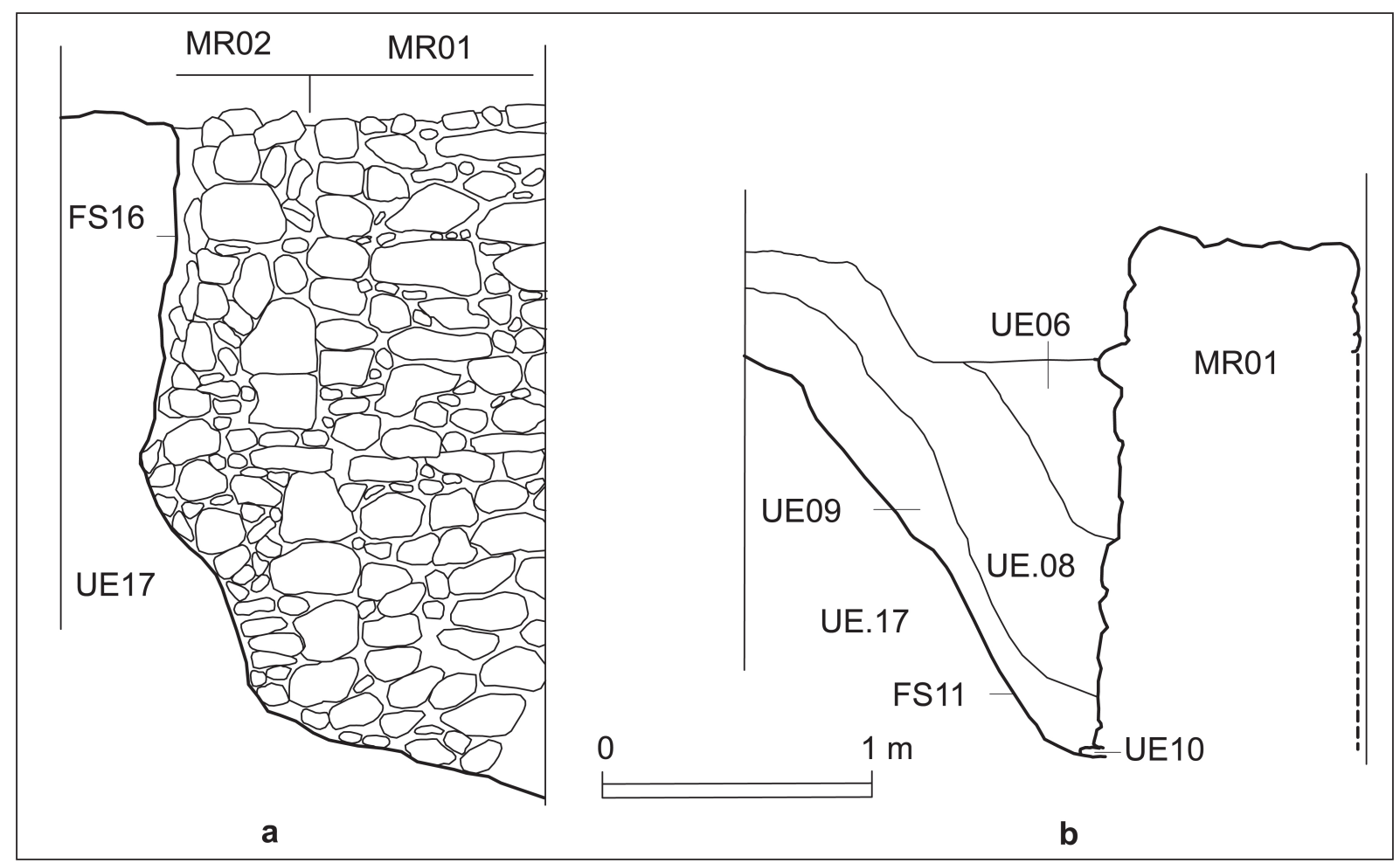

Figura 8. Alzado de la conexión entre MR01 y MR02 y perfil estratigráfico de los rellenos de la fosa de construcción de MR01.

correspondientes a un ánfora griega SOS, concretamente del tipo "ático 2" de Docter, fechable en la segunda mitad del siglo VII a.C.

\subsubsection{Contenedores de tamaño medio y reducido: jarras.}

\subsubsection{Jarras de boca ancha}

La pieza definida por un fragmento de la parte media-alta del cuerpo (fig. 13.11) pertenece a un pythos, así como de cuello y borde, con línea roja interna (¿de la misma pieza?) (fig. 13.9). La primera tiene el interés especial de presentar un motivo estrelliforme de seis radios en la parte alta, en negro, sobre franja roja y, además, cinco franjas rojas anchas y diez líneas negras conservadas.

El motivo estrelliforme tiene paralelos en un pythos de la sepultura 3 del Cortijo de las Sombras (Arribas y Wilkins 1971: 220, fig. 3, ab. izq. y lam. V), en este caso con ocho radios en cada cara, pero de distinto tamaño. En el Cerro del Villar, corte 5, estrato IV (Aubet 1999: fig. 61 f), corte 4, estrato 2 (Curià et al. 1999: fig. 137 k) y IIb (fig. 173 d-e, 184 g), también en la cerámica asociada a los enterramientos de la necrópolis de Jardín, en un caso sobre oenocoe, y en otros dos sobre jarros de un asa sobre el borde y boca ancha, en un claro ambiente de los siglos VI y V a.C., asociada a otros motivos como palmas y espigas (Schubart y Maass-Lindemann 1995: 290, p.e. figs. 19 n. 290, de la tumba 88, fig. 20 n. 336, de la tumba 101 y fig. 29, de la parte baja de la necrópolis; otro jarro de boca ancha con estrelliforme en López 1971-73: fig. 8). En la necrópolis denominada del Faro, en la isla de Rachgoun, uno de los pythoi hallados presenta dos bandas superpuestas de motivos de este tipo (Vuillemot 1965: fig. 17, tipo 2b).

Junto a ello, cabe destacar, por un lado, un fragmento de pythos de gran tamaño con decoración bícroma, que procede de la fase III del Cerro de la Era de Benalmádena (Suárez y Cisneros 1999: 108), fechada entre mediados del siglo VII e inicios del VI a.C. Esta pieza está decorada, al menos, con tres estrelliformes superpuestos de seis radios, que cabe suponer formarían bandas horizontales continuas. Cerca de la Era se localiza el Castillo de Fuengirola, sitio donde se ubicó el asentamiento de Suel, de donde procede un trozo de galbo de una posible jarra carenada decorada con motivo estrelliforme (Martín e Hiraldo 2018: 35). 


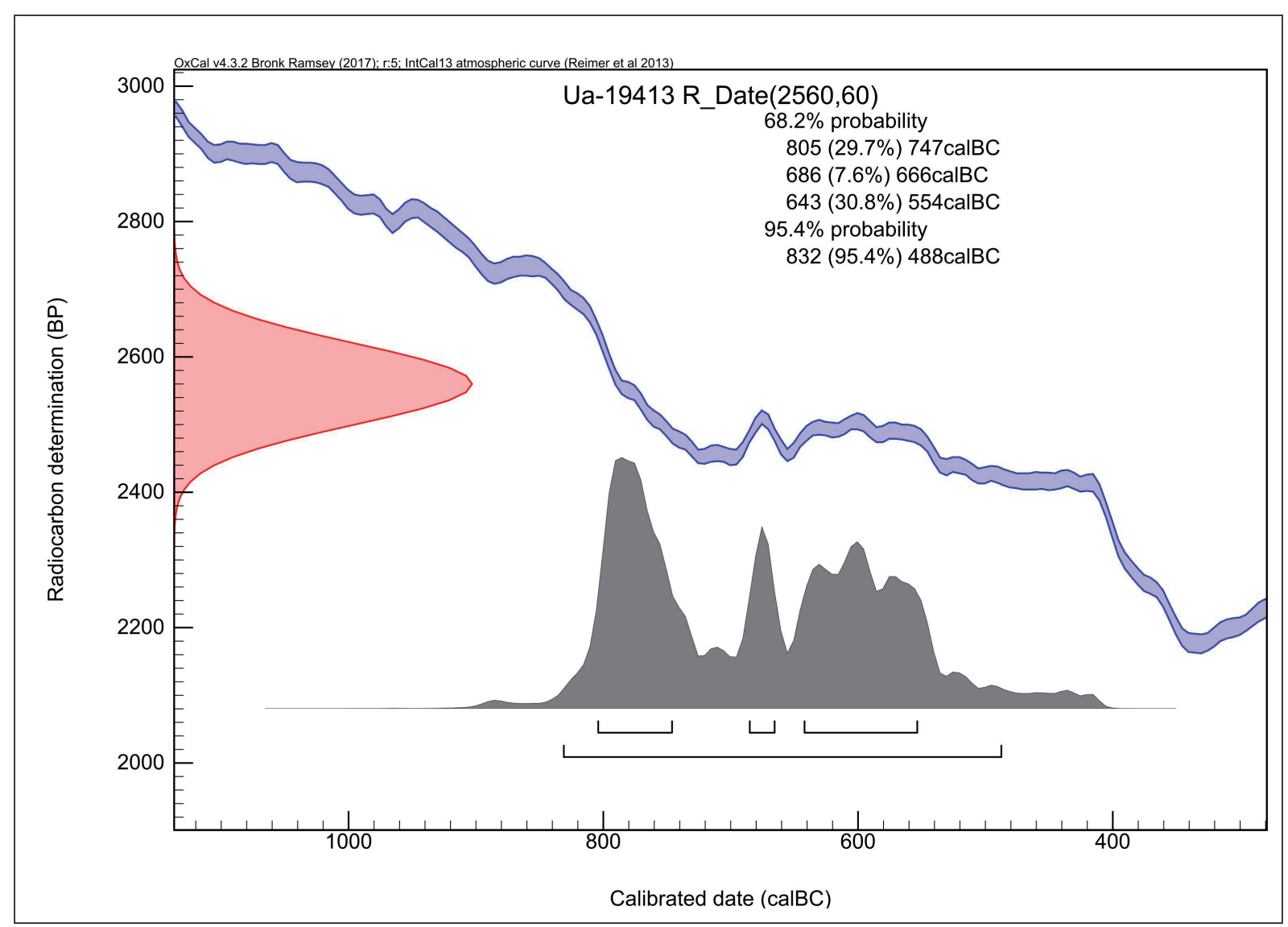

Figura 9. Datación de ${ }^{14} \mathrm{C}(\mathrm{Ua}-19413 \mathrm{R}, 2560 \pm 60 \mathrm{BP})$, realizada sobre muestra de carbón, procedente de la UE09.

Por lo que se refiere a este motivo decorativo, cabe apuntar dos cuestiones. La primera, que al menos entre el material publicado, por ahora, se halla invariablemente sobre pythoi y nunca sobre jarras tipo Cruz del Negro; en cambio, en el siglo VI y aún después, aparece sobre oenocoes y sobre jarros de boca ancha. La segunda, que su distribución se circunscribe de modo muy estricto al área de la actual provincia de Málaga, donde se han encontrado hasta la fecha todos los ejemplos, debiéndose considerar, con toda lógica, la pieza de Rachgoun, antes mencionada, una importación malagueña.

Si bien la representación de una estrella es un motivo astral tan antiguo y extendido como sus posibles significados, cabe recordar aquí, en función de los paralelos aducidos, la recurrente presencia de este motivo en las monedas de la ceca de Malaka (Málaga) (Campo y Mora 1995: 107-113, 120-121; CNH 100.1, 102.21 ss.). La lectura iconológica que se ha propuesto para este motivo en la amonedación tardopúnica malacitana se basa en la posible interpretación de conjunto de los reversos de estas amonedaciones y su posible relación con Shamash/
Sol: astro y divinidad del panteón fenicio, pero puede que también referencia genérica al Extremo Occidente, de la que participan otras amonedaciones del entorno del Círculo del Estrecho como Gadir con la representación de Helios/Shamash de frente en sus primeras emisiones (CNH 84.14), y sobre todo la todavía problemática ceca norteafricana de mqm $\check{s} m \check{s}$. La inclusión de este nombre - ̌́mš - en alguno de los cuños de Malaka, en una emisión del siglo I a.C. asociada a un templo tetrástilo, parece insistir en una lectura mítico-geográfica para estas iconografías monetales (Mora 2011: 22), y puede que también para el motivo de la estrella en las cerámicas malacitanas que comentamos.

Al mismo tipo de vaso corresponden, además, un fragmento de la UE08 (fig. 12.5), que se circunscribe a la parte superior del cuello, con un borde fino, exvasado y horizontal, y parte del asa geminada; también un fragmento de cuerpo situado por encima de la zona de máximo diámetro (fig. 12.6) que está decorado con tres líneas negras paralelas enmarcadas por dos franjas anchas de pintura roja. 


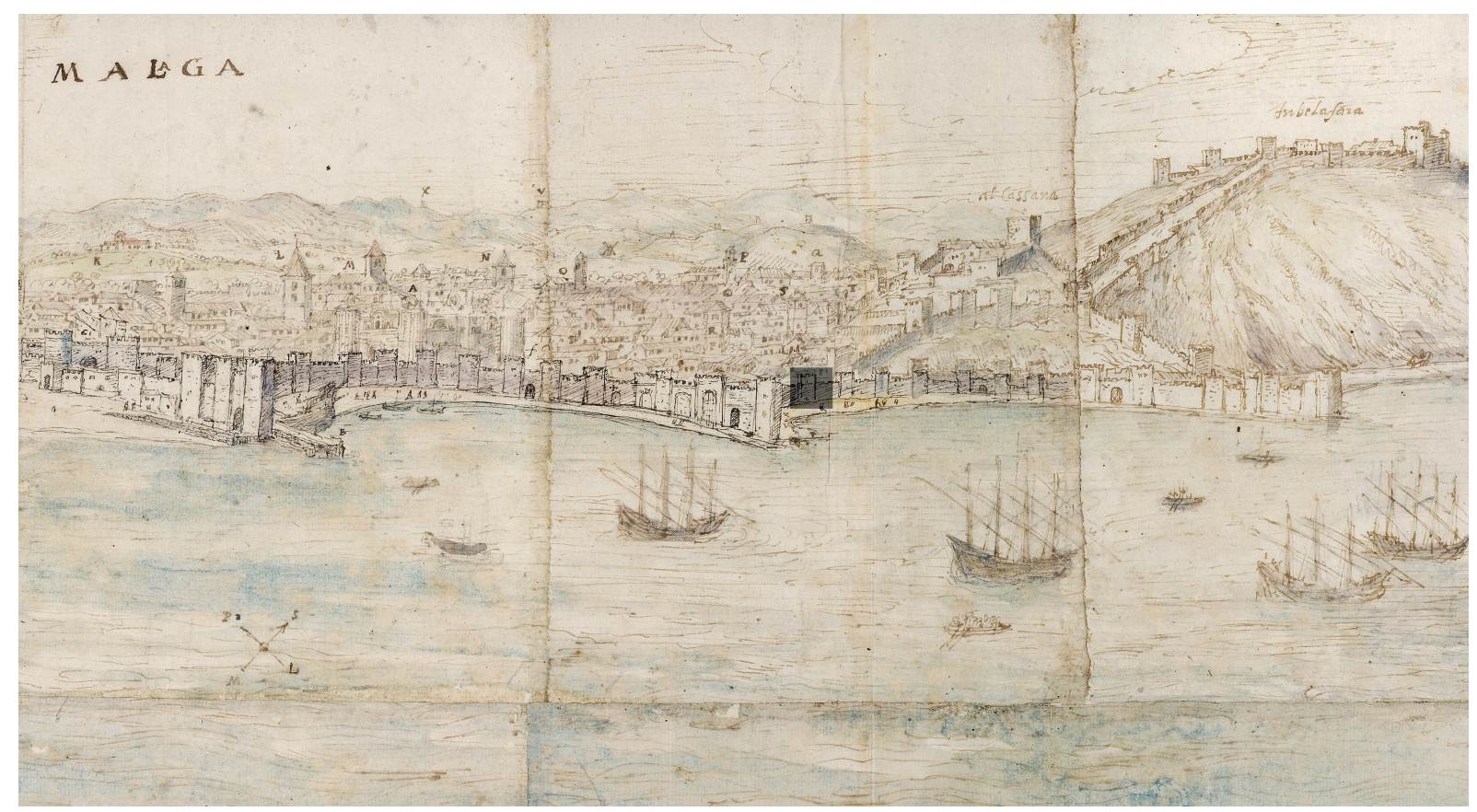

Figura 10. Vista del frente costero de la ladera sur de la colina de la Alcazaba en 1564, según A. van den Wyngaerde. Se observan, en el cuadro sombreado, las defensas medievales del denominado tercer recinto de la Alcazaba derribadas en el siglo XIX, donde se ubica al antiguo Edificio de Correos (C Ashmolean Museum, University of Oxford).

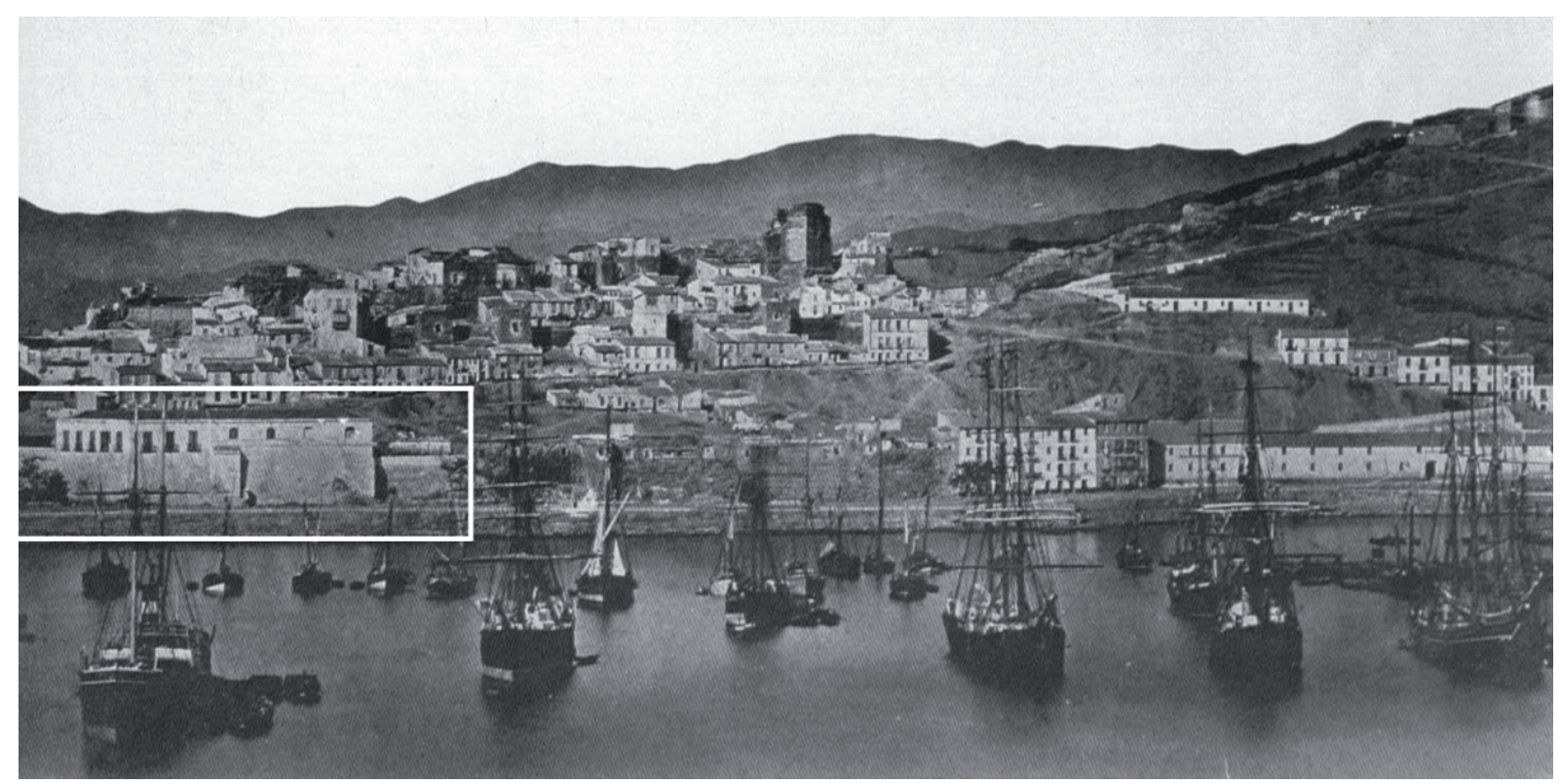

Figura 11. Imagen del sector de la ladera de la colina de la Alcazaba con anterioridad a la construcción del Edificio de Correos (Archivo Temboury. Diputación de Málaga). 


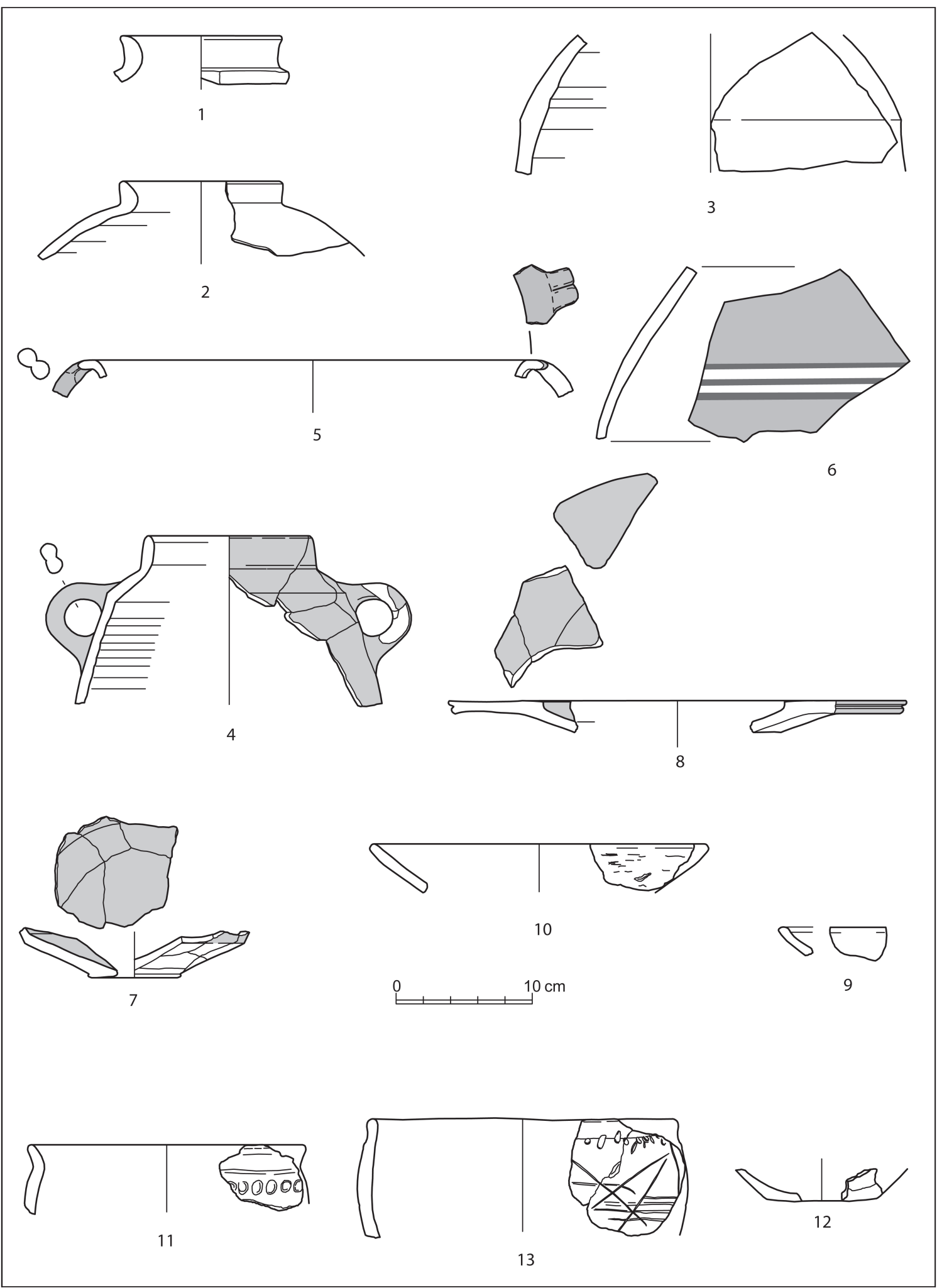

Figura 12. Materiales arqueológicos procedentes de la UE08. Cerámica a torno: ánforas (1 a 3), jarras (4 a 6), plato de engobe rojo (8), cuenco de engobe rojo (7) y cuenco gris (9). Cerámica a mano: cuenco (10) y ollas (11 a 13). 


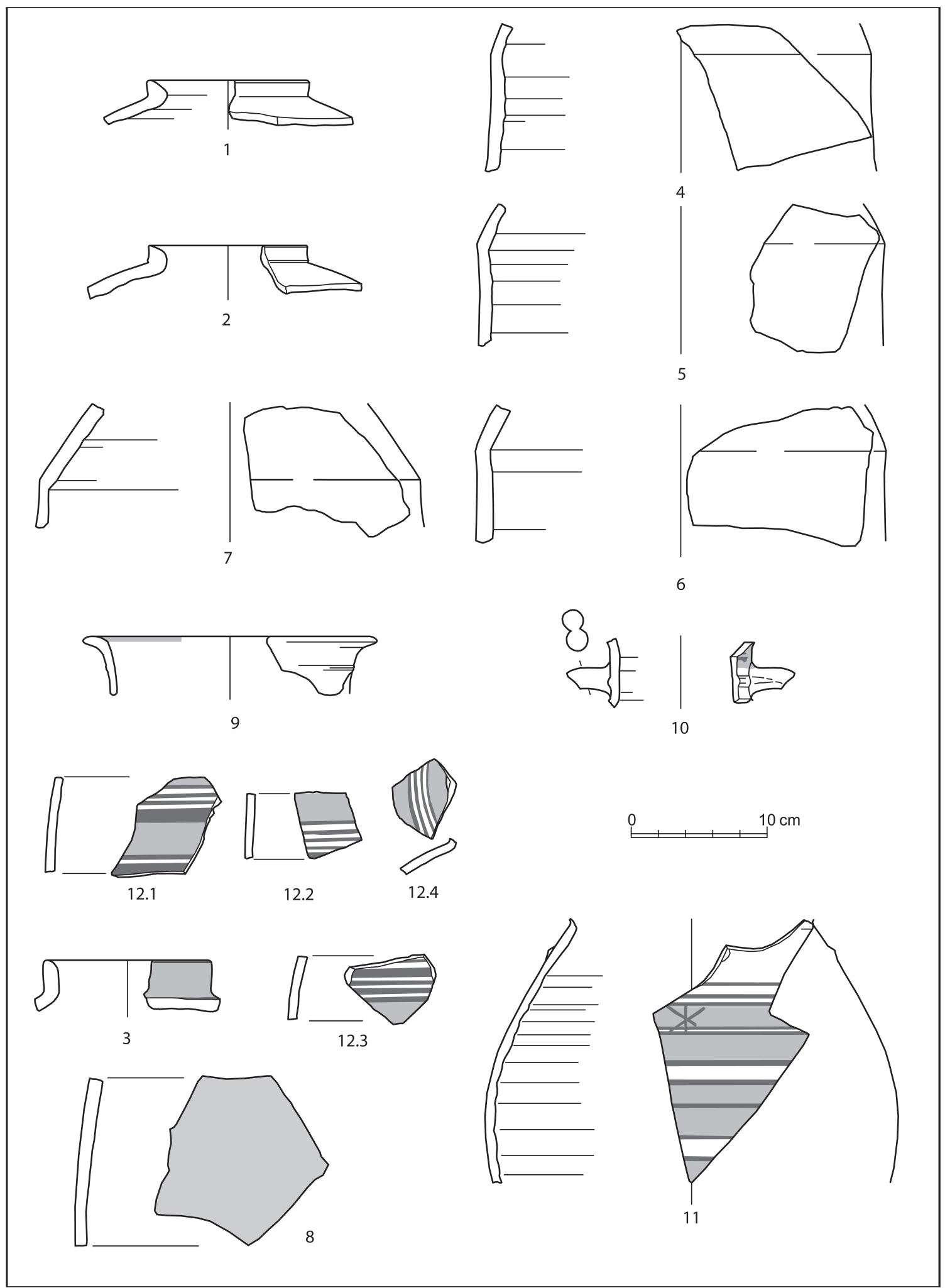

Figura 13. Materiales arqueológicos procedentes de la UE09. Cerámica a torno: ánforas (1, 2, 4 a 7) y jarras (3 y 8 a 12.4). 


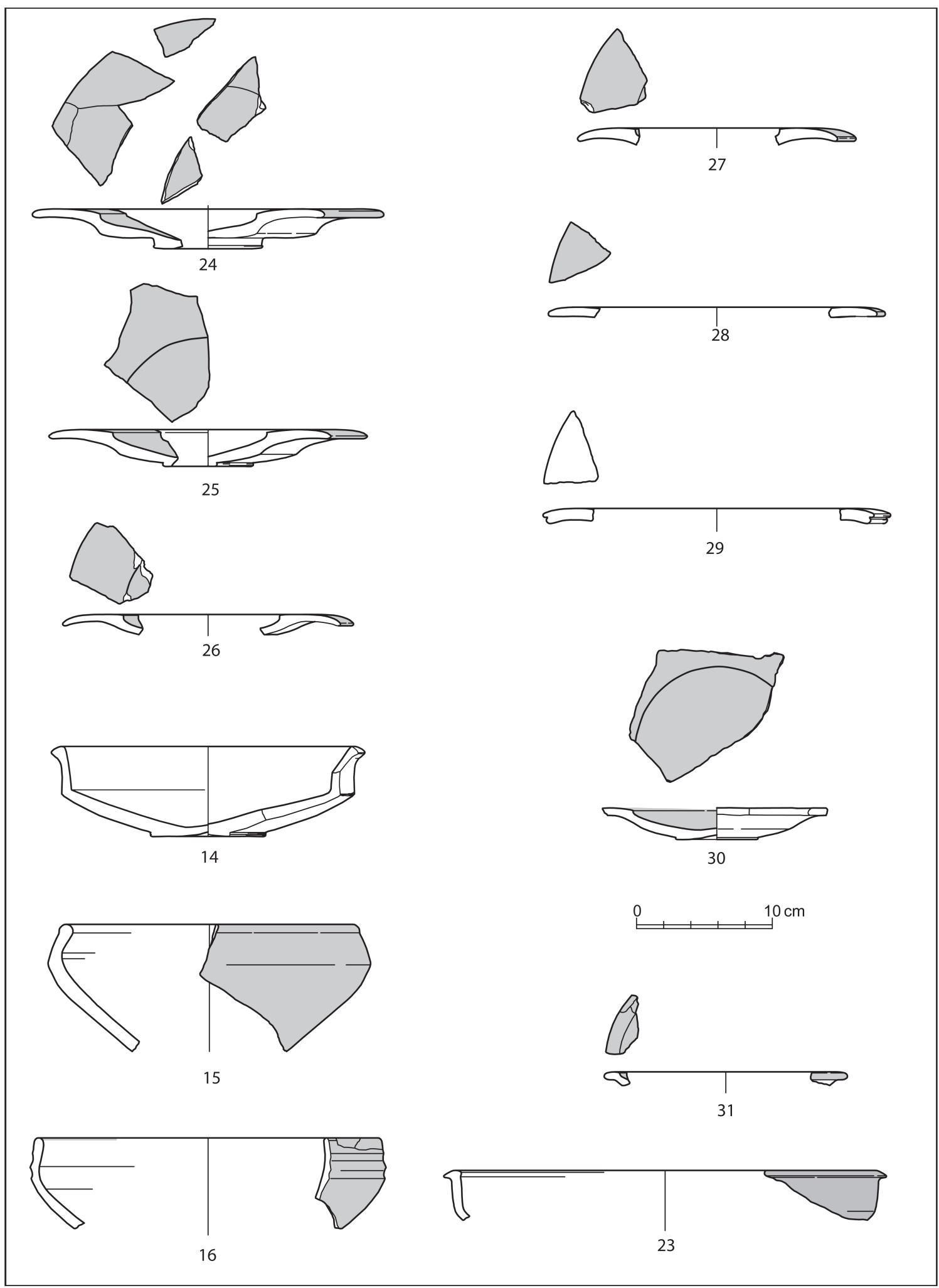

Figura 14. Materiales arqueológicos procedentes de la UE09. Cerámica a torno: platos de engobe rojo (24 a 30), cuencos de engobe rojo (14 a 16 y 23) y lucerna de engobe rojo (31). 


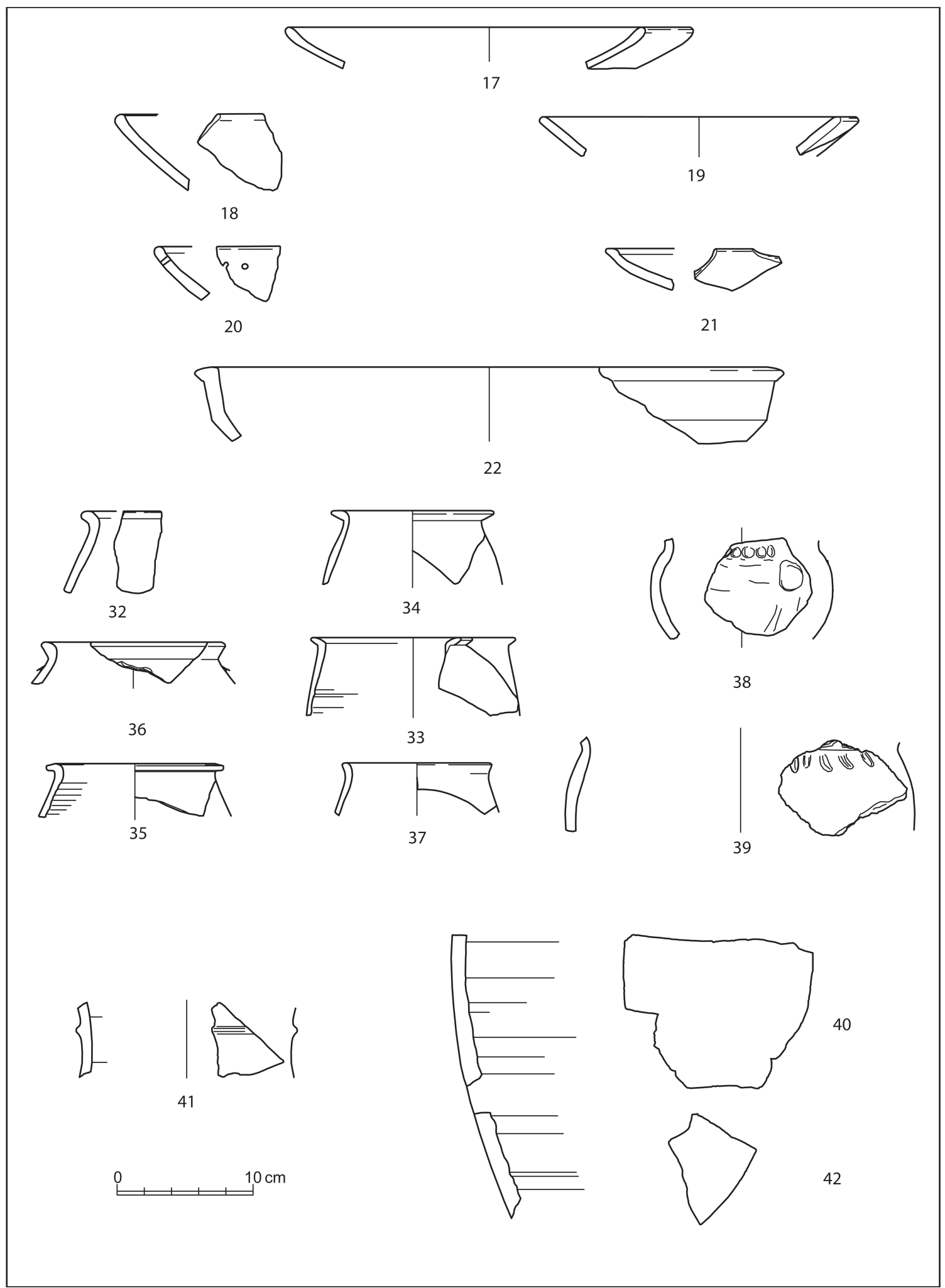

Figura 15. Materiales arqueológicos procedentes de la UE09. Cerámica a torno: cuencos grises (17 a 21), cuenco bizcochado (22), ollas a torno (32 a 37) y ánfora griega (40 a 41). Cerámica a mano: ollas (38 y 39). Varias escalas. 


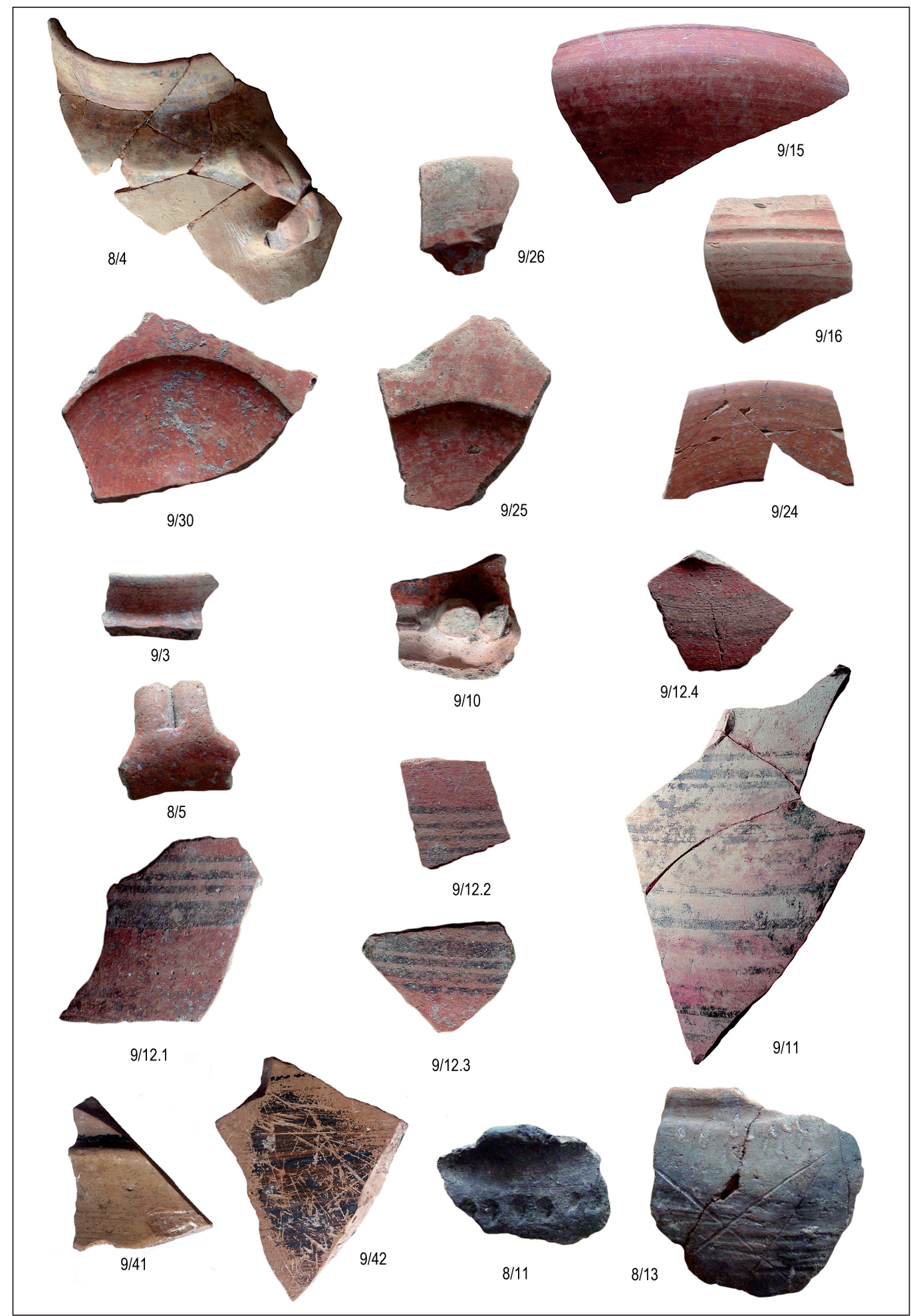

Figura 16. Selección de fragmentos cerámicos procedentes de las UEs 08 y 09 . Vajilla de engobe rojo: cuencos $(9 / 15$ y $9 / 16)$ y platos $(9 / 24,9 / 25,9 / 26$ y $9 / 30)$; jarras: jarra de engobe rojo $(8 / 4)$ y jarras pintadas $(8 / 5,9 / 3$, 9/10, 9/11, 9/12.1, 9/12.2, 9/12.3, 9/12.4; cerámica a mano: ollas (8/11 y 8/13); ánfora griega (9/41 y 9/42) (varias escalas). 
Otros fragmentos de cuerpo, con decoración bícroma, combinando un diferente número de líneas negras, más finas, con bandas rojas más anchas, son difíciles de atribuir a este tipo de jarra o al que se describe a continuación (fig. 13.12.1 a 13.12.3).

\subsubsection{Jarras de cuello cilíndrico estrecho}

El material clasificable en este tipo vascular, denominado comúnmente "Cruz del Negro", se corresponde, por un lado, a un fragmento perteneciente al cuello y parte superior de una de las asas procedente de UE09 (fig. 13.10). Dicho cuello tiene una proyección muy vertical, con nervio, redondeado y protuberante, en la parte baja. En la zona superior una franja roja, cruzada por dos líneas discontinuas paralelas en negro; el asa es geminada.

Un fragmento corresponde a la espalda del recipiente y su tramo conservado apunta claramente a un cuerpo esférico, decorado con dos franjas anchas de pintura roja que enmarcan cuatro líneas paralelas finas de pintura negra (fig. 13.12.4).

\subsubsection{Jarras de espalda carenada}

De esta clase se documentan tres piezas: la primera (fig.13.3) se reduce a un borde, alargado, de proyección vertical, con pintura roja en su cara externa y, en la base, una raya o banda negra. Jarras de este tipo, con el mismo esquema decorativo, se documentan en Cerro del Villar, corte 4, estrato 2 (Curià et al. 1999: fig. 158 b) y en el horizonte 1a del Cerro del Prado (Ulreich et al. 1990: abb. 21,1 -con labio muy inclinado hacia dentro) y, sin embargo, aparece también ya en el horizonte 2 de la Fonteta (González 2011a: fig. 20 núm. 20167 y 53776 y 21).

La segunda, de la UE08 (fig. 12.4) conserva el perfil de todo el tercio superior, íntegramente cubierto con engobe rojo. A ella puede añadirse un fragmento de cuerpo de gran formato, igualmente con engobe rojo en la cara externa (fig. 13.8).

Sea cual sea su técnica decorativa, se trata también de un tipo vascular bien conocido en el repertorio fenicio del extremo Occidente, a partir de la excavación de las tumbas de Trayamar y, de hecho, estas jarras, al menos las decoradas por el exterior con engobe rojo, suelen denominarse tipo "Trayamar 2" (Schubart y Niemeyer 1976: 212-213, lám. 12 núm. 547, 557, 48 c, 49 c-d y lám. 16. 606, 52 b). También de la campaña de 1971 en Los Toscanos proceden otros individuos fragmentarios (Schubart y Maass-Lindemann 1984: 82-85, fig. 3 núm. 110-113).
Otros hallazgos conocidos se ubican en la sepultura 1 del sector E de Puente Noy (Molina y Huertas 1985: 129, fig. 81, lám. IX) y en las tumbas 12, 16 y 118 de Rachgoun (Vuillemot 1955: 16). En el nivel IV Mogador se señalaron no menos de diez piezas, mayoritariamente con engobe rojo por el exterior, pero algunas con bandas pintadas (Jodin 1966: 91-93, fig. 21 d, 24 c y ¿a?, pl. XXXI).

Cabe mencionar también el estudio de Roald Docter (1997), quien atribuye a su tipo CdE 2B las piezas de Trayamar, Puente Noy y Rachgoun, entre otras. Dicho trabajo tiene como base los materiales de Toscanos y Cartago, pero abarca un radio geográfico más amplio, al cual, en fechas más recientes, se han sumado los también significativos hallazgos de este tipo de sa Caleta (Ramon 2007: fig. 14 núm. I-6, 94 núm. XXXI-35) y la Fonteta (González 2011a: fig. 19 núm. 37013, 20 núm. 34979, 35853 y 11771, fig. 21), confirmando, por otro lado, cronologías anteriores al final del siglo VII a.C.

\subsubsection{Oil bottle}

Solo se ha localizado un fragmento de cuerpo en UE09 que pertenece con claridad a uno de los pequeños contenedores de cerámica común, así denominados, sin decoración o tratamiento especial. De nuevo, y a pesar de su escaso porcentaje, se trata de una de las formas clásicas de época fenicia, puesto que es raro el yacimiento de esta cultura, o de radio de acción comercial fenicia, que no esté afectado por su presencia.

A pesar de que la rotura de la pieza impide algunas precisiones morfológicas, el perfil piriforme de su cuerpo, con diámetro máximo en posición media-baja, parece indicar que se trata de una variante con el fondo de forma ojival, con o sin mamelón, que por su pasta fina y amarillenta, podría pertenecer a un taller oriental. En todo caso, se trata de una variante que, a partir de la segunda mitad del siglo VII a.C, sustituye paulatinamente otros modelos con base anular (Ramon 1982, Orsingher 2010).

\subsubsection{Platos}

Conviene abordar también bajo premisas métricas los materiales de este tipo registrados en los estratos arqueológicos objeto del presente análisis que, por otro lado, constituyen un lote significativo, que se enumera a continuación:

- Borde de proyección horizontal, con ápice simple curvo (fig.14.24). Se caracteriza, además, por una 
fuerte inflexión externa a la altura del límite interior del borde, que le confiere un perfil acentuadamente angular, por debajo de cuyo accidente el perfil es prácticamente horizontal y levemente convexo. Diám. máx. $25,9 \mathrm{~cm}$, anch. del borde $5 \mathrm{~cm}$, cociente diámetro máx. / anch. borde: 5,18.

- Borde de proyección horizontal (fig. 14.25), ligeramente sobreelevado, con ápice simple curvo. Presenta una moderada inflexión externa a media trayectoria del perfil externo. Diám. máx. 23,5, anch. del borde 4,7, cociente diámetro máx. / anch. borde: 5 .

- Borde de proyección horizontal (fig. 14.26), ligeramente colgante, más convexo que en los dos casos anteriores, con ápice simple curvo, sin inflexión externa. Diám. máx. 21,4 cm, anch. del borde 4,5, cociente diámetro máx. / anch. borde: 4,75.

- Borde (fig. 14.27) similar al anterior en sus aspectos generales. Diám. máx. 20,5, anch. del borde 4,3, cociente diámetro máx. / anch. borde: 4,77.

— Borde (fig. 14.28) semejante a los números 24 y 25, incompleto.

- Borde (fig. 14.29) de proyección horizontal, convexo, de ápice bilobulado, incompleto.

- Perfil casi completo de plato (fig. 14.30) a excepción del ápice del borde; más bien bajo.

- Borde de proyección horizontal (fig.12.8), ligeramente sobreelevado, con ápice bilobulado, trayectoria externa levemente convexa, sin aristas ni carenaciones. Diám. máx. 33,7, anch. del borde 7, cociente diámetro máx. / anch. borde: 4,8.

Se registran, además, otros pequeños fragmentos de bordes simples, fragmentos de cazoletas, de perfiles inferiores y de bases, todos ellos con engobe rojo.

Como se ha visto, la mayoría de los fragmentos de este tipo presenta una capa delgada de engobe rojo, por lo general adherente, aunque puede estar muy perdido, con tonalidades que abarcan desde el rojo-marrón castaño $(2.5 \mathrm{YR} 4 / 8)$, al rojo claro $(2.5 \mathrm{YR} 5 / 8)$ y rojo vinoso (10R 4/8), que cubre toda la cara interna y solo la parte del borde en la externa. Al exterior pueden aparecer engalbas blanco-amarillentas (5Y 8/2).

En cinco de los casos puede, con garantías, calcularse el cociente diámetro máximo / ancho del borde, que da valores entre 47 y 52, mientras que los anchos absolutos de los bordes se mueven entre 4,3-4,8 cm tres de ellos, $5 \mathrm{~cm}$ en otro caso y $6,9 \mathrm{~cm}$ en el último. En Toscanos IV, referente no exento de problemas para pleno siglo VII a.C., los anchos de borde oscilan entre 3,6 y $5,8 \mathrm{~cm}$, mientras los cocientes lo hacen entre 45 y 75 , con concentraciones entre 45 y 49 . En realidad, la considerable anchura del borde de uno de los individuos (fig. 12.8) se ve compensada por su gran diámetro, de casi $34 \mathrm{~cm}$, mientras que su arquitectura no ofrece indicios que apunten a una forma manifiestamente tardía.

Otra característica común a los platos descritos es la tendencia de los bordes a la horizontalidad con oscilaciones pequeñas y también el hecho de tratarse, en todos los casos, de piezas visiblemente poco profundas. El plato (fig. 14.24) tiene, incluso en sus detalles, un paralelo estricto en la fase Fonteta II (González 2011c: fig. 10 núm. 823).

Con la excepción de los representados en las figs. 12.8 (UE08) y 13.29 (UE09), los bordes, en todos los casos, son de ápice simple redondeado, detalle también de interés cronológico, puesto que, si bien es cierto que los estriados aparecen ya en un momento muy antiguo, lo es también el hecho que su valor porcentual no es realmente alto hasta un horizonte datable muy a final del siglo VII y en los primeros decenios del VI a.C.

El conjunto de platos estudiado entra plenamente en los parámetros de Toscanos IV y de la fase II de La Fonteta, por citar solo dos horizontes significativos y, por tanto, no es posterior a c 625 a.C., pudiendo, incluso, ser algo más antiguo.

\subsubsection{Cuencos}

\subsubsection{Cuencos carenados de borde triangular exvasado con engobe rojo}

La pieza de la UE09 (fig.14.14) tiene paralelos bastante claros en Toscanos (Schubart y Maass-Lindemann 1984: taf. 5, 152), dónde se clasifica como tipo VI2, concretamente en el estrato 2 de la habitación C de la casa $\mathrm{H}$, fechado a principios del siglo VII a.C.; en Ceuta existen materiales similares (Villada et al. 2010: fig. 66 núm. 051/80). Alfredo González lo clasifica como tipo 17, variante B2b (González 2014a: fig.70 núm. 53948, entre otros) y está bien representado en la fase II del yacimiento.

Por otro lado, y siempre dentro de este tipo, la base y fondo de UE08 (fig. 12.7) tiene paralelos estrictos en sa Caleta (Ramon 2007: fig. 44 núm. a-44). En consecuencia, estas dos piezas, datables a lo largo del siglo VII a.C., podrían ser relativamente antiguas.

Finalmente, un borde de cuenco de la UE09 (fig. 14.23) se diferencia de los anteriores por presentar una carena mucho más atenuada, con borde triangular fino y exvasado y un diámetro máximo en relación a 
la altura, mucho mayor que las piezas descritas de esta serie, en cuya órbita morfológica, y a pesar de ser distinto en detalle, parece entrar. Se conservan solo restos de barniz rojo en el extremo superior del labio.

\subsubsection{Cuenco convexo con acanaladuras exteriores}

De este tipo existe únicamente un individuo en la UE09 (fig. 14.16) que presenta, además de esta característica, engobe rojo (7.5R 5/8) que cubre solo la parte exterior, pero no la interna, como también es típico del modelo.

Se trata de un elemento vascular de perfil abierto, aunque relativamente alto, convexo y borde generalmente entrante, con una o dos acanaladuras de sección redondeada por el exterior.

La pieza de Correos corresponde al tipo C1a de Pilar Rufete (1989: 379 y 386, figs. 3 a y 7 núm. 6 y 7), definido a partir de ejemplares del cabezo de San Pedro y la calle del Puerto, núm. 6, fechados por la autora en la primera mitad del siglo VII a.C. En Toscanos, tratados con engobe rojo, fueron clasificados como tipo VIII 2b (Schubart y Maass-Lindemann 1984: 102-103, fig. 9 núm. 249 y 250). El individuo 249 pertenece al estrato $6 \mathrm{~b}$ del corte 15 , seguramente de avanzado el siglo VII a.C. Se documenta, igualmente, en el Cerro de Alarcón (Maas-Lindemann 1988: 211, lám. 19 núm. 394), pero sin contextualizar.

En el Castillo de Doña Blanca (Ruiz y Pérez 1995: fig. 20 núm. 8 -pieza excepcional por conservar el perfil casi completo-) aparece en horizontes fechados, sin más precisión, en el siglo VII a.C., aunque con posibles precedentes en el siglo VIII a.C. (id. fig. 17 núm. 8). Por otro lado, está bien documentado en el sondeo del colegio de San Agustín de Málaga (Recio 1989: 102-104, fig. 30, núm. 17B, 16, 18C,4 y 21A,4), donde los tres casos claros parecen relacionados con la estratigrafía (niveles 17, 18 y 21) correspondiente a las construcciones anteriores a la muralla, probablemente de los primeros decenios del siglo VI a.C. Existen también en Mogador (López y Habibi 2001: fig. 5 núm. 210-211), aunque con cronología menos precisa.

En Ceuta, todos los ejemplares registrados se sitúan en el techo de la secuencia (fase IIc), es decir, en el último momento estratigráfico conservado, que es próximo al 600 a.C. (Villada et al. 2010: 131, núm. 006/19, 014/139, 020/12).

Sin embargo, este tipo de pieza que, por otro lado, a veces aparece decorada con la técnica black on red, con pintura bícroma y motivos en retícula e incluso en pasta gris, se documenta en la fase II de la Fonteta (González 2014b: fig 72, 1303, f 73, 51011, tipo 40), hecho que, al menos en el área mediterránea, garantiza su presencia en horizontes anteriores a c. 650-640 a.C.

\subsubsection{Cuenco convexo con borde entrante y ligeramente engrosado}

El único individuo de esta clase (fig.14.15) presenta engobe rojo en toda su cara externa, pero no en la interior. Sin paralelos estrictos por el momento, en cierto modo podría estar emparentado con los cuencos de acanaladuras exteriores, pero sin esta característica específica.

\subsubsection{Cuencos de cerámica gris}

El material de este tipo está representado por fragmentos de UE08 (fig. 12.9) y de UE09 (fig. 15.17 a 15.21). Cinco de ellos son cuencos convexos, relativamente abiertos, cuyo borde en ningún caso se halla realmente flexionado hacia el interior y apenas pueden considerarse como engrosados, característica, esta última, común en numerosos cuencos de esta clase, a la cual, y aunque de modo atenuado, pertenece una pieza (fig.15.20).

Piezas similares a las de Correos, de borde no engrosado, se encuentran asociadas al nivel de funcionamiento del horno 1 del sector 9 del Cerro del Villar (Delgado 2011: fig. 10, 2a fila desde abajo) y aparecen en la fase II de la Fonteta, englobados en el tipo 15 de Alfredo González (2014a: fig. 17 núm. 50330, 19 núm. 33844, 20 núm. 38613, 36981, 24 núm. 52172, 26 núm. 37303, 35892, 36867, etc.).

Caso aparte es una pieza de UE09, con una cara superior moderadamente convexa y el ápice ligeramente exvasado (fig. 15.21) que responde a un tipo de borde distinto a los anteriores, no lejano al $16 \mathrm{~A}$ de la Fonteta, también enmarcado en la fase II del yacimiento (González 2014a: fig. 36 núm. 20301).

\subsubsection{Cuencos de cerámica común, carenado y borde triangular exvasado}

Es un modelo en realidad poco conocido, que existe, por ejemplo, en sa Caleta (Ramon 2007: fig. 4, S-97), aunque fuera de contexto. Tal vez pudiera asimilarse al tipo 41 de La Fonteta (González 2014b: 654, fig. 75). Sin duda se trata de un gran cuenco de procesamiento (fig. 15.22).

\subsubsection{Lucernas}

Entre el material de Correos se han documentado dos fragmentos de lucernas fenicias a torno. Uno de ellos 
(fig. 14.31), es un fragmento del borde de la cazoleta y lleva engobe rojo en su cara superior, mientras que el segundo corresponde a la parte del pliegue para formar uno de los picos y no tiene tratamiento.

En realidad, ambos carecen de otra utilidad que no sea testificar la existencia de este tipo en el complejo estudiado, sin aportar nada nuevo en cuanto a morfología o aspectos cronológicos, debido a su grado de fragmentación.

\subsubsection{Ollas de cerámica común}

Corresponden, genéricamente, al tipo Toscanos XVI-1 (Schubart y Maass-Lindemann 1984, taf. 17 y 18), Alarcón V B (Maass- Lindemann 1988: 208-209, lám 17 y 18), González 8A y 8B (borde vuelto) y son abundantes en la fase II de la Fonteta (González 2011b: 395-404, fig. 1-5), con perduraciones más escasas en las fases posteriores (fig. 15.32 a 15.37).

En todo caso, cabe señalar que el tipo, con borde más o menos saliente, se documenta ya en Las Chorreras (Aubet et al. 1979: fig. 9 núm. 119, 11 núm 155), durante la segunda mitad del siglo VIII a.C. En cuanto a su continuidad durante el VII a.C. se documenta en el Cerro del Villar, asociado al nivel constructivo del horno 1 (Delgado 2011: fig. 9).

\subsection{La cerámica a mano}

Junto a la poca representatividad numérica de este conjunto vascular objeto de análisis dentro de este horizonte de la excavación, la cerámica a mano destaca por su escasa variabilidad formal. Se documentan mayoritariamente formas cerradas, correspondientes a vasos de tamaño medio y pequeño del tipo ollas u orzas, y algunos cuencos. Se trata en todo caso de formas propias de repertorios de tradición autóctona, bien caracterizadas en recientes trabajos de síntesis sobre estas producciones en el ámbito malagueño (García 2007: 296).

En general, este tipo de vasijas suele presentar porcentajes poco significativos en los asentamientos coloniales -especialmente a partir del siglo VII a.C.- como ya se observó hace años, por ejemplo, en Toscanos, donde no alcanzaba el $3 \%$ del total del conjunto cerámico documentado en el yacimiento (Schubart et al.1969: 128). En los contextos de la propia Malaka fenicia, como Teatro Romano y San Agustín, su presencia es inferior al $1 \%$ en momentos iniciales del siglo VI a.C. (Recio 1990: 153).

\subsubsection{Las ollas}

Las ollas se caracterizan por presentar cuerpos ovoides o globulares con una suave inflexión en su extremo superior que lo separa del borde y consecuente ausencia de cuello. El borde puede ser ligeramente exvasado (fig. 12.11) o marcadamente saliente (fig. 15.38). Respecto al fondo, del que en realidad solo se conserva un fragmento (fig. 12.12), es simple y plano. Una de las piezas presenta indicios de haber dispuesto de un asa (fig. 15.38), que arrancaría bajo el borde. En el hombro es habitual la presencia de decoraciones consistentes en series de impresiones de aspecto redondeado u ovalado (fig. 12.11 y 12.13 , fig. 15.38 y 15.39), mientras que el cuerpo puede adornarse con trazos incisos (fig. 12.13).

Vasos de estas características fechados en el siglo VIII a.C. se documentan, por ejemplo, en el vecino poblado autóctono de San Pablo, localizado en la margen derecha del río Guadalmedina, donde aparecen masivamente en la UE07 (Fernández et al. 1997: 234, fig. 8.3 a 8.12). En la cuenca del bajo del Guadalhorce están presentes en Taralpe (Alhaurín de la Torre) también en momentos avanzados de la misma centuria, donde cabe señalar la presencia de ejemplares monoansados en la UE03 (Santamaría, Suárez y Ramon 2012: 199: fig. 7, $\left.\mathrm{n}^{\mathrm{o}} 1216\right)$.

En términos generales, esta forma está presente en la mayoría de los yacimientos fenicios coetáneos peninsulares, incluidos los de la propia bahía de Málaga, como el Cerro del Villar, estrato V del Corte 5 (Aubet 1999a: 60, fig. 8, s/n), correspondiente al siglo VII a.C., de donde procede un ejemplar con asa exenta, así como la ciudad de Málaga, en sitios como la ladera opuesta de la colina de la Alcazaba (Gran-Aymerich 1991: 197, n 6) o en el sondeo de San Agustín (Recio 1990: 88), ya en contextos de la primera mitad del siglo VI a.C.

Su representación dentro de los contextos coloniales ha dado pie a analizar el papel desempeñado por estos recipientes de cocina de tradición autóctona en los asentamientos fenicios, habiéndose vinculado a la presencia de poblaciones locales en los mismos, en particular a mujeres (Delgado 2008: 73).

\subsubsection{Los cuencos de casquete esférico}

Junto a las ollas, la forma predominante en los repertorios de la cerámica de tradición del Bronce Final-inicios de la Edad del Hierro son los cuencos de casquete esférico (García 2007: 276). Se trata de vasos con 
superficies poco cuidadas, con tonos grisáceos, resultado de una cocción en atmósfera irregular. Los labios pueden ser simples o ligeramente engrosados al interior (fig. 12.10).

Los mejores paralelos para esta forma se localizan en la propia bahía de Málaga, concretamente en la UE07 del poblado indígena de San Pablo (Fernández et al.1997: 226, fig. 6.9 a 6.11) fechada en momentos del siglo VIII a.C., y aguas arribas del valle del Guadalhorce están presentes en Los Castillejos de Teba (García 1994: fig. 8, a-c), asentamiento de finales de dicha centuria.

En los contextos del siglo VI a.C. de San Agustín se ha documentado un fragmento de escudilla a mano de un total de 6 ejemplares manufacturados, que en conjunto representan el $0,4 \%$ del total de la cerámica de los contextos fenicios (Recio 1990: 155, fig. 55, n 21 ), lo que ejemplifica bien la progresiva pérdida de esta tradición alfarera en los complejos vasculares coloniales entre los siglos VIII al VI a.C.

\subsection{La cronología de los complejos vasculares del horizonte inicial del solar del edificio de Correos}

El Cerro del Villar continúa siendo un referente básico para las cronología del material fenicio occidental entre el último cuarto del siglo VII, momento al cual se atribuye el estrato IV del corte 5 (Aubet 1999b:91), y los primeros decenios del VI a.C., representados por los estratos III y II del mismo corte y, en general, el estrato II del sector 3/4 (Aubet 1999b: 92-93, Curià et al. 1999), pero que otros autores (Torres et al. 2014: 79) circunscriben, aún más, entre 580-560 a.C. Otros puntos de anclaje cronológico válidos, esta vez en la propia ciudad de Málaga, vienen dados por el sondeo de San Agustín (Recio 1990) y los estratos inferiores del Teatro (Gran-Aymerich 1991), con complejos estratigráficos fechados en el primer tercio del siglo VI a.C. Tanto en unos como en otros, la presencia de significativos ejemplos de cerámicas griegas y etruscas constituye una base firme para dichas dataciones.

En el caso del estrato IV del corte 5 del Cerro del Villar, sin cerámicas de esta clase, pero perfectamente estratificado por debajo de los niveles antes citados, es también un indicio que, hasta no se demuestre lo contrario, puede avalar perfectamente la cronología del último cuarto del siglo VII a.C., sugerida por su editora (Aubet 1999b: 91).

Diversas razones, que se argumentan a continuación, inducen a fechar la fase fenicia del antiguo solar de
Correos en un momento anterior al estrato IV del corte 5 del Cerro del Villar y, por tanto, antes de c 625 a.C., siempre y cuando - cabe insistir una vez más- se considere válida la datación de dicho estrato. Del mismo modo también son anteriores, sin lugar a duda, al periodo III del Cine Cómico en Cádiz, que sus editores, con buen criterio, asignan al ventenio 600-580 a.C. (Torres et al. 2014: 79), así como al periodo I del Castillo de San Sebastián, también en Cádiz, e igualmente del 600-580 a.C. (Maya et al. 2014: 177).

El primero de estos argumentos es de carácter técnico. Por ejemplo, en el Cerro del Villar, el engobe rojo, a partir de este momento «adquiere una calidad y una dureza extraordinarias, hasta el punto de confundirse a primera vista con una capa de barniz» (Aubet 1999b: 90). En segundo lugar, destaca la total ausencia de una serie de formas que irrumpen en el escenario vascular en los horizontes citados, como lebrillos, cuencos espuerta, nuevos tipos de platos mucho más evolucionados, igual que sucede con las ánforas, que de hecho corresponden ya al T-10211 o se hallan en el punto de transición de este tipo con el T-10121. Tampoco el material de Correos refleja ningún aumento espectacular de la cerámica gris, $\mathrm{y}$, en cuanto a las pintadas, con decoraciones profusas y diversas a partir del estrato IV del corte 5 del Cerro del Villar (Ramon 2010: 227), cabe señalar que en Correos no parecen aún haber llegado a este estadio.

La mayoría de los platos de Correos refleja arquitecturas de pleno siglo VII a.C., igual que sus tamaños y proporciones. Solo en un caso -un plato, sin embargo, con un diámetro importante- tiene un borde de $6,9 \mathrm{~cm}$ de ancho, medida que se enmarcaría en el muy mal conocido, dicho sea de paso, Toscanos $\mathrm{V}$ y en los materiales contenidos en los rellenos de las tumbas de Trayamar, cuya morfología, en el caso de estos últimos, es distinta a la del plato núm. 11 de Correos. De hecho, en la Fonteta II se documentan platos con bordes incluso sensiblemente más anchos (González 2011c: tabla de la pág. 580) y cocientes aún mucho más bajos, situación que invita claramente a no rebajar excesivamente la cronología de esta pieza.

Por su parte, los cuencos grises, con bordes apenas engrosados, son relativamente abiertos y no tienen la marcada inflexión hacia el interior típica de muchas producciones de esta serie, que sin embargo, como ya se ha visto antes, se compone de modelos que se documentan desde la época de Chorreras y de Fonteta I.

Lo mismo puede decirse de las ollas globulares ansadas, algunas de las cuales, en el caso de Correos, tienen un borde particularmente saliente. A pesar de que 
cabe admitir que una subclasificación de este típico modelo es, por ahora, complicada -no se olvide la elevada proporción del material fragmentario, pero los pocos ejemplares completos-, vasos con este tipo de borde están también presentes en Chorreras y en una fase antigua del Cerro del Villar.

Otro punto de anclaje cronológico a considerar, como en cierto modo ya se ha anticipado, viene dado por la ausencia / presencia o incluso por el porcentaje relativo de determinadas cerámicas griegas. Mientras que el ánfora SOS es una pieza del siglo VII a.C. y, de hecho, un tipo de elemento habitual en un buen número de horizontes estratigráficos de esta centuria, pero siempre en un porcentaje muy pequeño, la afluencia de cerámicas de la Grecia del Este no se produce en los yacimientos del sur peninsular, sino a partir del 600 a.C., o muy poco antes, pero solo con evidencia abrumadora desde el segundo cuarto del VI a.C.

Los estratos de la excavación del Rectorado de la Universidad de Málaga parecen situarse con claridad antes de este momento y, por otra parte, son comparables en todos sus extremos con la fase II de La Fonteta, como se ha ido viendo en el análisis específico de cada una de las piezas. Por todas estas razones, la cronología que, en cifras absolutas se propone, se sitúa en el tercer cuarto del siglo VII a.C. o, más concretamente, en $c$ 650-630 a.C. Así pues, la componenda vascular que forma el complejo cerámico de los dos estratos del solar que nos ocupa, aquí estudiados, se enmarca perfectamente en el "horizonte M4", definido por uno de nosotros (Ramon 2010: 225 -226, figs. 3-4).

\subsection{Procedencia del complejo vascular}

El conjunto cerámico (salvo un par de piezas que pueden atribuirse a importaciones) corresponde a vasijas elaboradas mayoritariamente a torno, con cocciones oxidantes o con núcleo reductor y acabado oxidante. Los colores dominantes son, para la cerámica a torno, rojo claro exterior $(2.5 \mathrm{YR} 7 / 6)$ y al interior gris oliva claro (5Y 6/2). Algunas piezas presentan engalbas blanco-amarillentas ( $5 \mathrm{Y} 8 / 2$ ). El engobe rojo y la pintura empleada en pythoi y jarras abarca desde el rojo marronáceo (2.5YR 4/8) al rojo claro (2.5YR 5/8) y al rojo vinoso (10R 4/8), así como líneas en gris muy oscuro $(2.5 \mathrm{Y} 3 / 1)$, y el tono de la cerámica gris es mayoritariamente el gris claro (5Y 7/1). La cerámica a mano abarca tonos preferentemente marrones anaranjados (5Y 6/4), con manchas color gris muy oscuro (2.5Y $3 / 1)$, propio de cocciones en atmósferas irregulares.
Respecto a las pastas cerámicas, la mayoría son groseras al tacto, duras, con textura irregular en la rotura, con inclusiones abundantes, con ordenación pobre. Tras su visión con lupa digital a 10 aumentos, se observa un predominio de las partículas grises-negruzcas y parduscas, de esfericidad baja, angulosas, con tamaños de fino a grosero y muy grosero, seguidas de nódulos blanco-grises traslúcidos, de esfericidad alta, subangulosos o subredondeados, de tamaño medio a grosero. También es frecuente la presencia de partículas blanco-mate de esfericidad alta y subangulosas, de tamaño fino a grosero (fig.17).

Junto a estas pastas, hay otro grupo que se diferencia del primero por presentar tacto suave al corte, inclusiones con ordenación muy buena y naturaleza semejante a las ya descritas, aunque en este caso el tamaño de las mismas va de fino a muy fino.

A nivel macroscópico, por comparación con la geología local y especialmente por sus semejanzas con los desgrasantes empleados en los vecinos talleres del Cerro del Villar, bien caracterizados petrológicamente (Cardell 1999), se puede proponer la identificación de visu de rocas como los esquistos, arenas con cuarzo, y partículas calizas, propias de los complejos metamórficos y sedimentarios que dominan este entorno. En concreto, destaca la presencia en el conjunto de inclusiones blanco-mate, que podían corresponder a nódulos de cal, una de las señas de identidad de los alfares fenicios localizados en la desembocadura del río Guadalhorce (Cardell 1999: 18).

Respecto a la presencia de dos grupos de pastas tecnológicamente diversos, cabe señalar que aquellas que presentan desgrasantes de tamaño fino o muy fino se asocian mayoritariamente a vajilla de mesa que suele presentar engobe rojo, siendo previsible la fabricación de ambos en los mismos talleres. Esta circunstancia se constata en el propio Cerro del Villar, donde las piezas destinadas al servicio de mesa se han fabricado con escasa presencia de desgrasante y en todo caso de pequeño tamaño (Cardell 1999: 19).

En este punto, ya que es obvio en todos los casos que sus características apuntan con claridad a la actual costa malagueña, la pregunta es ¿de qué talleres exactamente? Aunque en ausencia de análisis complejos del material, como ya apuntamos, una respuesta definitiva es arriesgada, la primera posibilidad, por ahora ni contrastada ni desmentida, es que en la segunda mitad del siglo VII a.C. existieran ya talleres en el propio ámbito urbano o suburbano de la propia Málaga (Mora y Arancibia 2010: 820). La respuesta a esta pregunta deberá esperar a que la investigación 


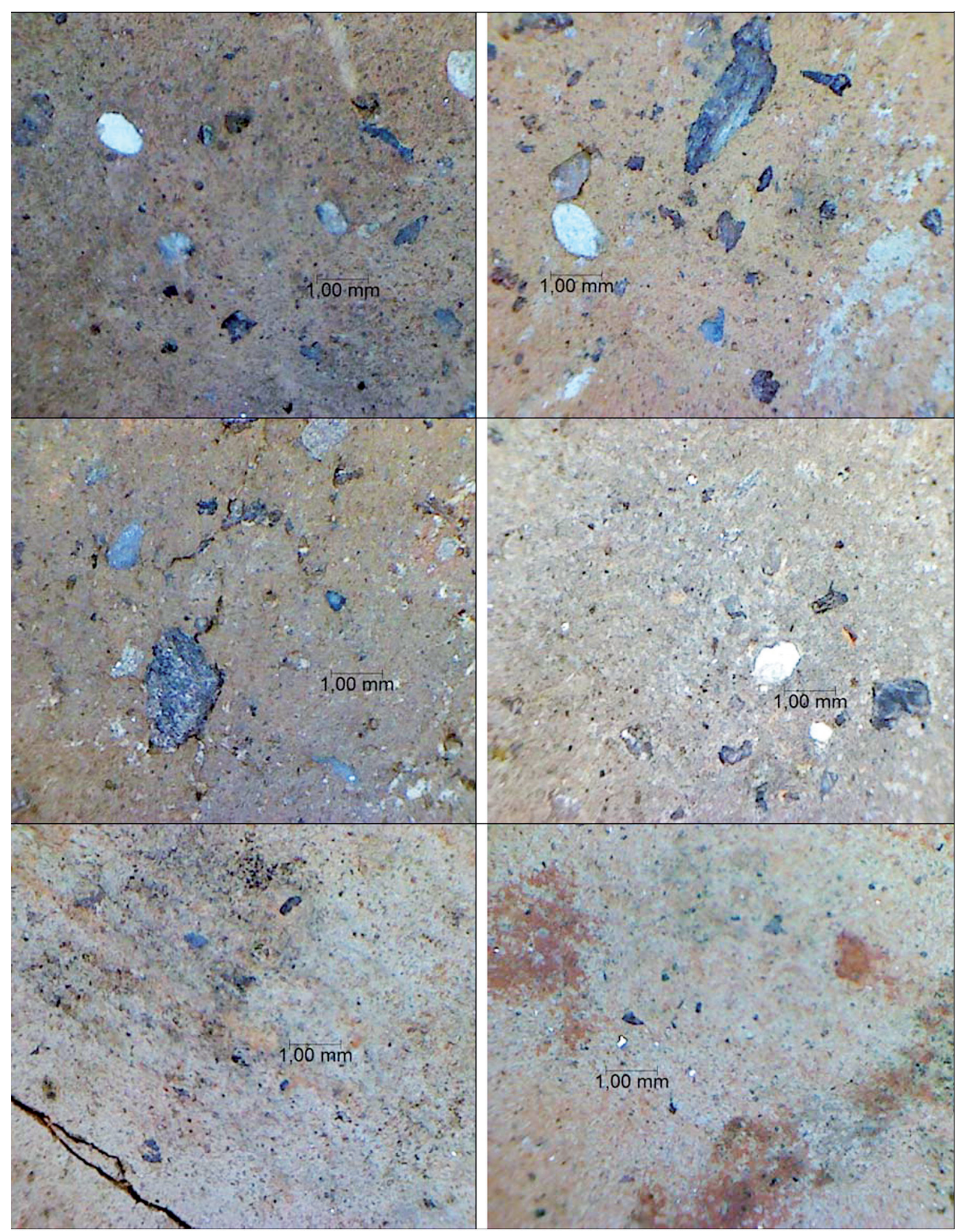

Figura 17. Detalle de pastas (x10 aumentos). Pastas groseras: $n^{\circ} 1(9 / 1)$, ánfora fenicia occidental; $n^{\circ} 2(9 / 12.3)$, jarra; $n^{\circ} 3$ (9/39), olla a mano; $n^{\circ} 4(8 / 9)$, cuenco gris. Pastas finas: $n^{\circ} 5(9 / 24)$, plato de engobe rojo y $n^{\circ} 6(9 / 26)$, plato de engobe rojo. 
avance, tanto en la exploración de nuevos solares como en estudios arqueométricos. La segunda posibilidad, no desdeñable en absoluto, sería que estos talleres se situasen en el área del Guadalhorce, a tan solo $6 \mathrm{~km}$ al oeste de la ciudad de Málaga. En este sentido, cabe no olvidar que en el enclave del Cerro del Villar se han documentado hornos cerámicos ya desde el inicio del siglo VII a.C. o, incluso, finales de la centuria anterior (Delgado 2011). Además, se cuenta con todo un complejo alfarero en el sector 3/4, que funcionó entre el final del siglo VII y el primer tercio del VI a.C. Pero, como se ve, unos por demasiado antiguos y otros por demasiado modernos, ninguno de ellos coincide en el tiempo con los conjuntos de Málaga (650-625 a.C).

La tercera y última posibilidad recurrente es el área productora costera entre los ríos Vélez y Algarrobo, territorio situado a unos 28-35 km al este de Málaga. En efecto, en estos puntos hay razones sobradas para pensar que las producciones vasculares fenicias, que hasta la fecha son las más antiguas occidentales documentadas, se iniciaron antes de mediados del siglo VIII a.C., con plena continuidad en los siglos inmediatamente sucesivos. No obstante, dado que una de las características de las pastas utilizadas en los complejos de Correos es la abundancia de puntos de cal, propia de los talleres del Guadalhorce, todo apuntaría a su probable vínculo con los localizados en la bahía de Málaga.

\subsection{Cuestiones de cuantificación}

En el presente estudio se ha realizado el doble cómputo característico, en un caso, por NR (número total de fragmentos, sin pegar) y, en otro, por NMI (número máximo de individuos, considerados aquí por bordes, con reducción a uno los que pegan entre sí), en cálculo no ponderado.

El NR global, sumando los dos estratos, es de 320 unidades (UE08: 54, UE09: 266), mientras que el NMI es de 46 (UE08: 12, UE09: 34). Se trata, por tanto, de un grupo numéricamente pequeño, pero, sin duda, no exento de significación.

Destaca, por un lado, el tema de las distintas producciones, según tecnología de fabricación (fig. 18), con el resultado, por NR: cerámica a torno $93,7 \%$, cerámica a mano $6,3 \%$ y por NMI: cerámica a torno $91,3 \%$, cerámica a mano $8,7 \%$.

En el ámbito de la cerámica a torno, los principales resultados obtenidos son los siguientes (fig. 19): por un lado, agrupando los vasos por categorías funcionales, el resultado es: ánforas NR 43,3\% NMI 11,9\%, contenedores medianos y pequeños NR 37,3\% NMI 9,5\%, platos con engobe rojo NR 7,7\% NMI 28,6\%, cuencos con engobe rojo NR 4\% NMI 9,5\%, cuencos grises NR $4 \%$ NMI $16,7 \%$, cerámica de procesamiento NR $0,3 \%$ NMI 2,4\%, cerámica de cocción NR 2,7\% NMI 16,7\%, lucernas NR 0,7\% NMI 4,8\%.

Si esto mismo se evalúa según categorías tecnológicas, el resultado es (fig. 20): cerámica común NR 69,0\% NMI 31,7\%, cerámica con engobe rojo NR 12,3\% NMI $43,9 \%$, cerámica gris NR 4,0\% NMI 17,1\%, cerámica pintada NR 13,7\% NMI 7,3\%, cerámica griega NR $1,0 \%$ NMI $0,0 \%$.

Un último cálculo se ha hecho con base en la procedencia de las piezas, con este resultado: cerámica a torno fenicia occidental NR 92,5\% NMI 91\%, cerámica a torno fenicia oriental NR 0,3\% NMI $0 \%$, cerámica a torno griega NR 0,9\% NMI 0\% y cerámica a mano, de tradición indígena, NR 6,3\% NMI 9\%.

Estos resultados permiten hacer algunas observaciones. La primera es que,en términos cuantitativos, el valor de la cerámica a torno frente a la de producción indígena alude con claridad a un contexto cultural puramente fenicio, semejante a lo observado en el resto de las colonias arcaicas coetáneas del Mediterráneo occidental.

La segunda se refiere a los valores porcentuales de las distintas clases funcionales. Entre estas, como se ve en los datos antes expuestos si se consideran por NR, los vasos contenedores, incluidas obviamente las ánforas, alcanzan un porcentaje de $80,6 \%$ que, en contrapartida, se ve reducido a tan solo el $21,4 \%$ por NMI. En este último terreno, los conjuntos de vajilla, categoría a la que corresponden los platos y cuencos con engobe rojo y los cuencos grises $(54,8 \%)$, superan holgadamente la mitad del conjunto total de cerámica a torno. Otro dato de interés es el porcentaje de elementos relacionados con el procesamiento de alimentos, incluida su cocción, que arroja valores de $19,1 \%$ por NMI y $2,9 \%$ por NR. Finalmente, los elementos de iluminación, como cabría esperar, tienen un porcentaje muy bajo.

De todo ello se infiere, claramente, que se trata de un conjunto vascular relacionado con prácticas de consumo doméstico, sin quedar de manifiesto ningún otro indicio de especialización distinta.

Otro aspecto también analizado aquí es el de las categorías de cerámica a torno, entre ellas la cerámica común, es decir, sin decoraciones, que por NR supera ampliamente al resto, sin embargo por NMI se halla, a su vez, superada por la vajilla con engobe rojo. Las 


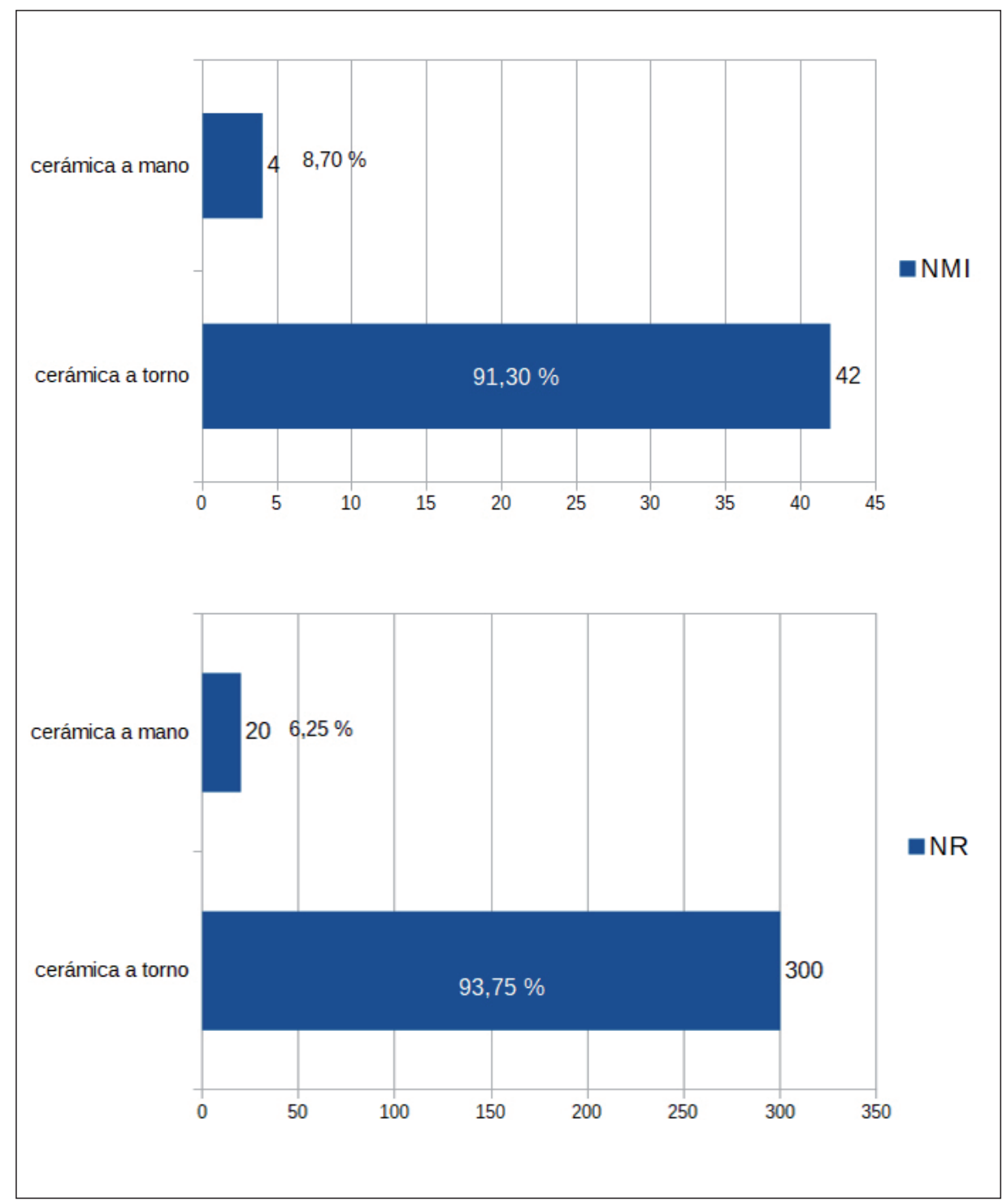

Figura 18. Porcentajes de producciones elaboradas a mano y a torno. UEs 8 y 9.

piezas de cocción reductora, aunque bien presentes, se hallan sensiblemente por debajo de las decoradas con el mencionado engobe. Finalmente, los vasos pintados no alcanzan el $15 \%$ en cualquiera de los dos sistemas de cómputo aplicados, aunque, como se ha indicado otras veces, juegan con una cierta desventaja, ya que no todas las partes del cuerpo están afectadas por la decoración.

Finalmente, queda por comentar el tema de las procedencias de la cerámica a torno, que se hallan absolutamente dominadas (NMI 100\%, NR 98,7 \%) por las producciones fenicias occidentales y en concreto del ámbito malagueño, ofreciendo las (testimoniales) oil bottles y el ánfora ática registradas una presencia normal en el panorama de cualquier asentamiento fenicio extremo occidental del siglo VII a.C.

\section{LOS DATOS DEL SOLAR DE CORREOS EN EL CONTEXTO DE LA BAHÍA DE MÁLAGA A INICIOS DE LA EDAD DEL HIERRO Y LA FASE INICIAL DE MALAKA}

El poblamiento fenicio de la bahía de Málaga destaca en el contexto del sur de la península ibérica por su antigüedad. El santuario de la Rebanadilla, situado sobre un islote localizado en pleno paleoestuario del río Guadalhorce, se remonta a momentos de la segunda mitad 


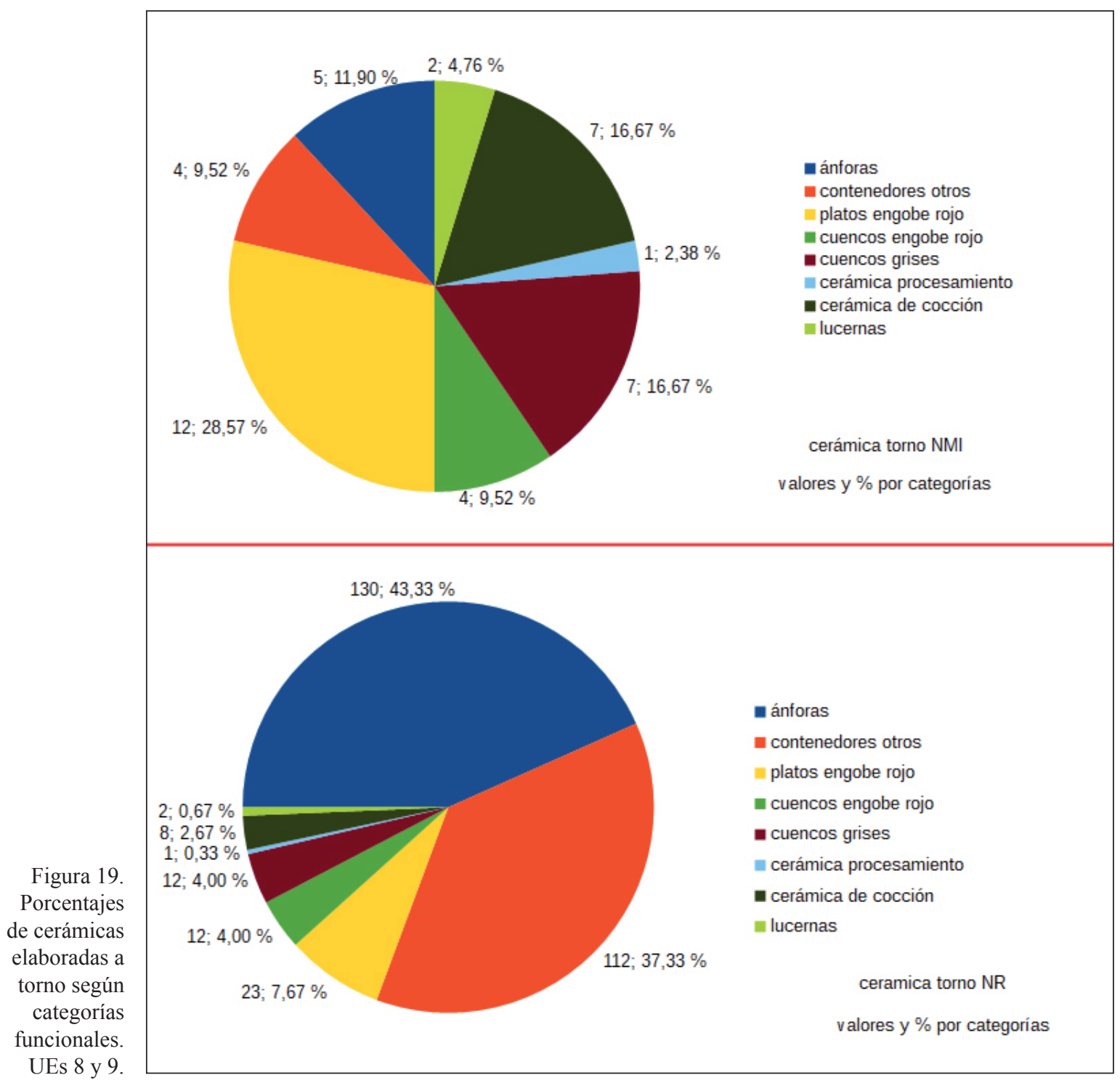

del siglo IX a.C. A finales del siglo VIII a.C. se abandonó este lugar y surgió un importante asentamiento en otra isla localizada a apenas $1,9 \mathrm{~km}$ del primero, en dirección al mar: el Cerro del Villar. Desde sus orígenes, estos sitios convivieron con poblados de origen autóctono de finales de la Edad del Bronce.

Estas circunstancias permiten analizar el ámbito malagueño como un caso concreto de paisaje colonial fenicio y su evolución en el tiempo, hasta que en el último tercio del siglo VII a.C. la propia Malaka se configurase como cabeza de territorio de toda la comarca (fig. 21).

El hallazgo de Rebanadilla fue resultado de los trabajos arqueológicos vinculados a la ampliación de una de las pistas del aeropuerto de la ciudad (Sánchez et al. 2012; Sánchez et al. 2018). Este yacimiento presenta una completa secuencia en la que se pudieron observar hasta cuatro fases bien diferenciadas, asociadas a una necrópolis dispuesta en tierra firme, el Cortijo de San Isidro. Al primer momento de actividad, denominado "Rebanadilla IV", se atribuyen una serie de fosas excavadas en el sustrato natural, donde se arrojaron diversos objetos, destacando algunos relacionados con la práctica de actividades metalúrgicas. Con poca diferencia de años tuvo lugar la fase denominada "Rebanadilla III", que corresponde ya a un asentamiento de algo más de 3 hectáreas delimitado por una cerca, con una serie de edificios construidos con adobes y ordenados por 


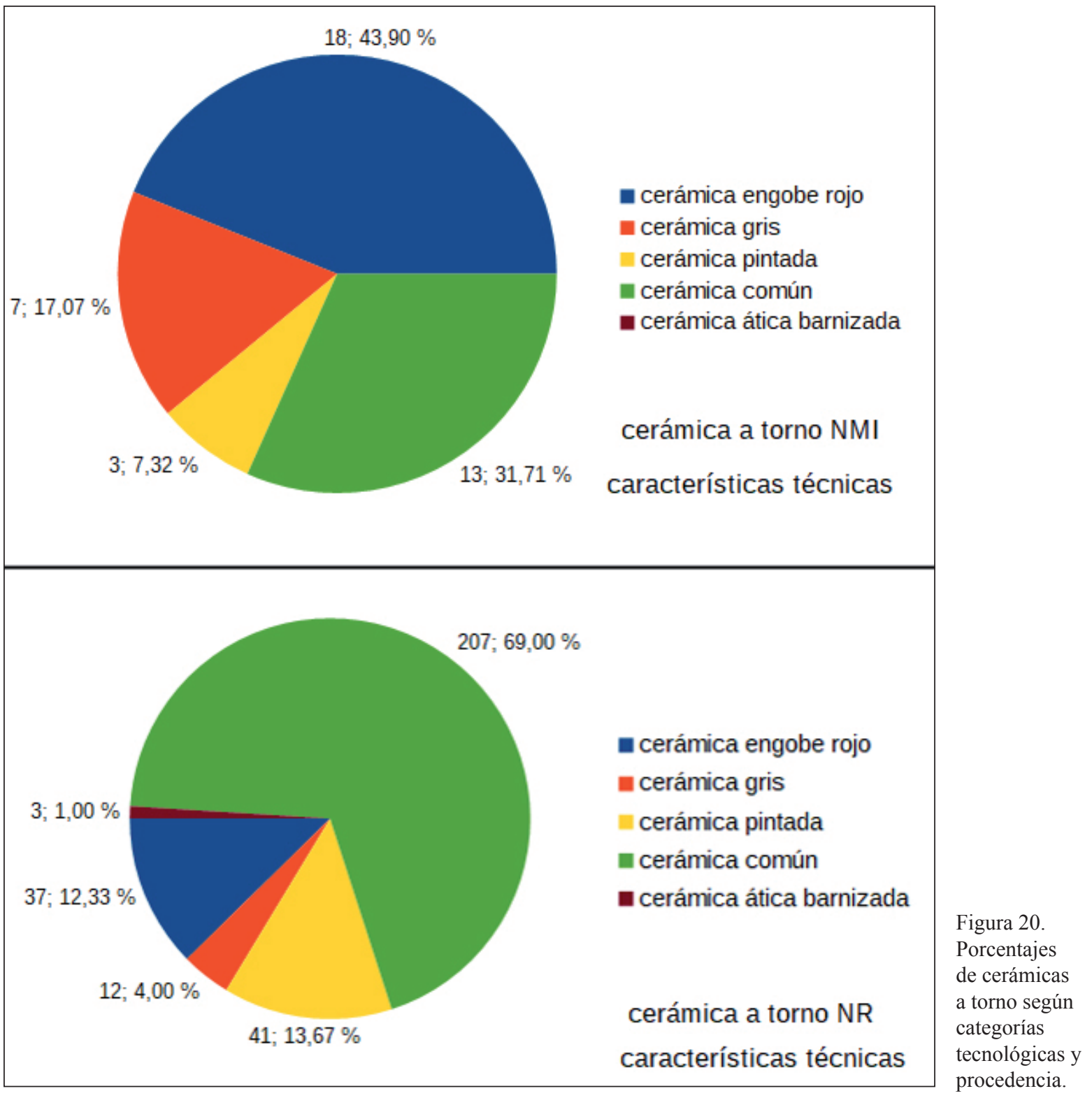

calles, que presentan planta ortogonal y diversas estancias articuladas a partir de zonas abiertas o patios. En alguno de los inmuebles han aparecido objetos que indican prácticas de actividades religiosas. La interpretación del sitio como santuario vendría avalada por el hallazgo de una serie de epígrafes de carácter sacro sobre cerámica (Sánchez et al. 2018). "Rebanadilla II" es una fase peor conocida, que se caracteriza por la presencia de edificios con zócalos de piedra y en algún caso, pavimentos de conchas marinas. Sobre los restos del antiguo poblado de Rebanadilla II se dispusieron cabañas elaboradas con materiales perecederos ("Rebanadilla I").
Respecto a la cronología propuesta para el asentamiento, sus orígenes se centran en momentos de la segunda mitad del siglo IX a.C., siguiendo tanto dataciones convencionales (basadas en la cronología aportada por un par de escifos del Geométrico Medio II) como radiocarbónicas (García 2016: 124).

El abandono de Rebanadilla se produciría en momentos de la segunda mitad del siglo VIII a.C. (Arancibia et al. 2011: 130). Por esas fechas, el asentamiento de mayor importancia en la bahía es el Cerro del Villar (Aubet et al. 1999: 47, Aubet 2018). Esta nueva colonia se fundó sobre un amplio islote con unas dimensiones cercanas a 


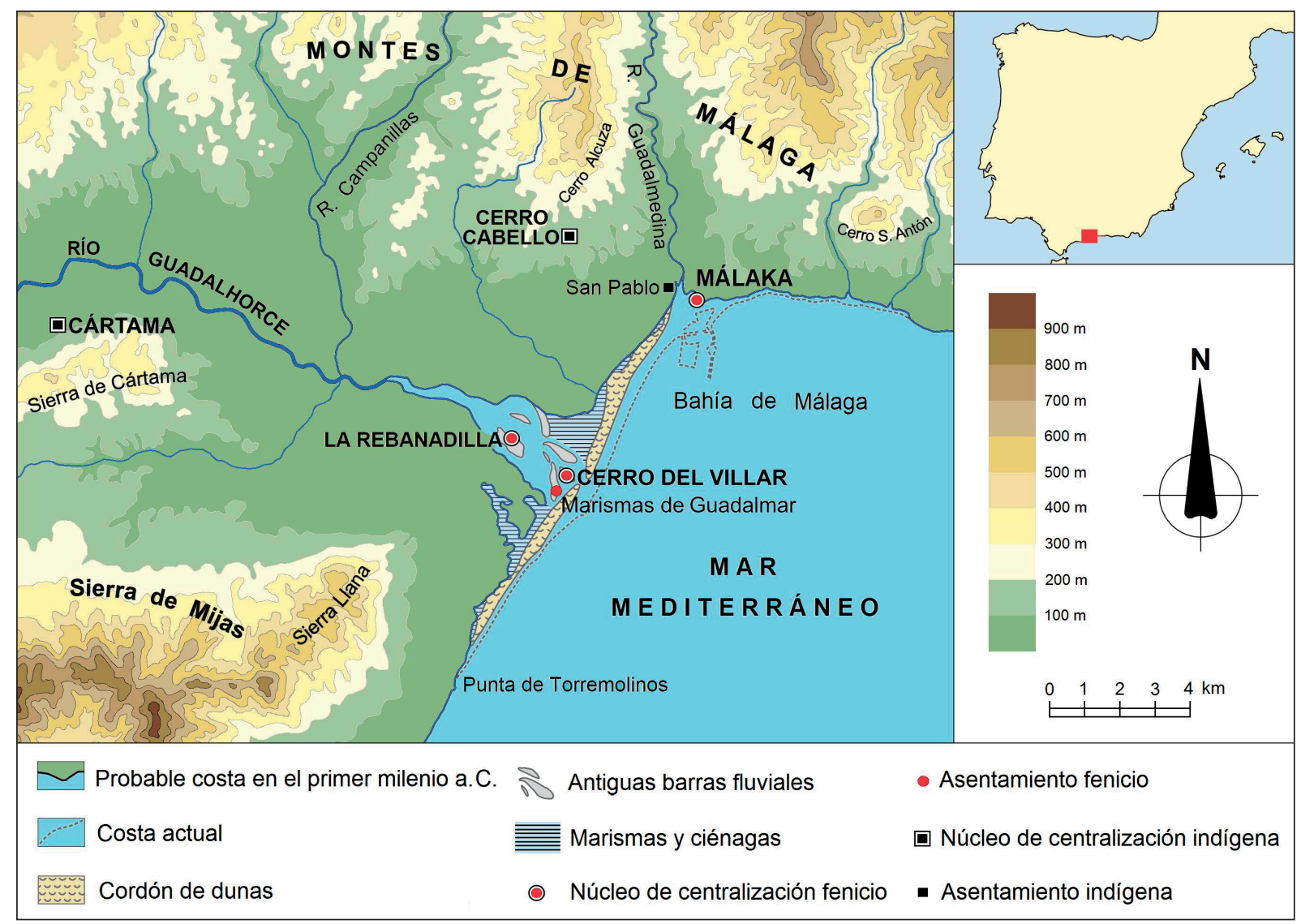

Figura 21. Poblamiento de la bahía de Málaga entre los siglos IX al VII a.C. (cortesía de E. García Alfonso).

las 10 hectáreas. En momentos avanzados del siglo VIII a.C. presentaba un urbanismo ortogonal planificado a partir de calles, algunas con $5 \mathrm{~m}$ de ancho, desde las que se accedía a grandes casas, fabricadas con zócalos de mampostería local recrecidos con adobe. Algunos de los inmuebles contaban con soportales, bajo los cuales se ha propuesto que se practicaron actividades de intercambio con la población local. También se ha constatado la presencia de talleres alfareros dedicados tanto a la fabricación de contenedores como de vajilla de mesa, así como otros destinados a actividades metalúrgicas. A partir de mediados del siglo VII a.C. y durante el primer cuarto del siglo VI a.C., el asentamiento parece orientarse específicamente a la producción cerámica (Aubet 1999b: 93).

En los primeros siglos del I milenio a.C. el segundo cauce fluvial en importancia de la bahía de Málaga, el Guadalmedina, conformaba a su vez un amplio estuario (Hoffmann 1988). En su margen derecha, sobre una suave colina de unas 5 hectáreas de superficie, entre las cotas 4 y 6 m s.n.m., se ubicó un poblado autóctono con orígenes en el siglo IX a.C., conocido como
San Pablo (Peral 2006: 213). De los primeros momentos del poblado se conocen restos de una cabaña elaborada con materiales perecederos, localizada en un solar ubicado entre las calles Tiro-Zamorano (Melero 2011: 2431). Se trata de una estructura de hábitat de planta oval, ligeramente rehundida en el sustrato geológico, con suelo de tierra apisonada y un hogar consistente en una torta de barro. Entre los niveles de colmatación se localizaron exclusivamente fragmentos de cerámica a mano, consistentes en vasos de almacenamiento de cuello corto y exvasado, junto a fuentes y copas de perfil cónico, profundo, con carenas angulosas y bordes cortos, formas presentes a su vez en los contextos más antiguos de Rebanadilla (Sánchez et al. 2012: 71, ilus. 6; 72, ilus. 8; 74, ilus. 11). También a estas primeras fases correspondería una de las fosas excavadas en la plaza de San Pablo, que aportó una fecha radiocarbónica de una muestra de carbón, la Ua-23136 (2785 \pm 45 BP), que calibrada, y con un $68 \%$ de probabilidad, se sitúa entre el 1.000 y el 840 cal BC (Arancibia y Fernández 2012: 57). Resulta 
de interés observar cómo esta datación viene a coincidir significativamente con las procedentes del santuario fenicio ubicado en el estuario del Guadalhorce (Sánchez et al. 2012: 69, fig. 2).

El poblado presenta un nuevo horizonte de ocupación, que con dataciones convencionales se sitúa en el siglo VIII a.C., detectado en la Fase II del propio solar de calle Tiro-Zamorano (UE29) y en el relleno (UE07) de otra fosa de grandes dimensiones de la plaza de San Pablo. En el primer contexto los materiales arqueológicos asociados presentan ya cerámicas fenicio-occidentales, limitadas a unas pocas categorías, entre las cuales están presentes las ánforas, alguna del tipo T-10121, junto a pythoi, cuencos y platos de borde estrecho de engobe rojo (Melero 2011: 2435, fig. 4). Respecto al segundo de los casos, la plaza de San Pablo (Fernández et al. 1997: 234, fig. 5), el conjunto cerámico asociado a este momento presenta más de un $90 \%$ de vasos realizados a mano de tradición del Bronce Final local, junto a escasas piezas torneadas fenicias, entre las que se encuentran varios fragmentos de pythoi, bordes de platos estrechos de engobe rojo y un trozo de dipper jug.

En momentos avanzados del siglo VIII a.C. se constata la creación de aldeas en el entorno del paleoestuario del Guadalhorce. Uno de los mejores ejemplos es el sitio de Taralpe (Alhaurín de la Torre) (Santamaría, Suárez y Ramon 2012), situado sobre la ladera de un arroyo subsidiario del río principal de la bahía, y próximo a las minas polimetálicas del Llano de la Plata. En este lugar se ha documentado parcialmente una amplia fosa, interpretada a priori como cabaña, donde se ha localizado un número significativo de cerámicas, entre las cuales las fabricadas a mano de tradición local siguen siendo dominantes, aunque se amplía el repertorio de producciones torneadas tanto cuantitativa como cualitativamente.

La organización del territorio durante el siglo VII a.C. es peor conocida en la comarca. En la margen derecha del Guadalmedina, el poblado de San Pablo presenta nuevas fases de ocupación, mal caracterizadas. En los solares de calle San Pablo 19 (Ferrando e Íñiguez 2011) y en el entorno de la plaza de San Pablo (Díaz 2011) se han documentado retazos de muros inconexos de edificios y espacios abiertos, en algún caso con presencia de pavimentos de conchas marinas.

En la margen izquierda del río Guadalmedina se localiza históricamente la ciudad de Málaga. En los primeros siglos del I milenio a.C. la paleotopografía de este ámbito se caracterizó por la existencia de dos promontorios: uno de mayor entidad, la colina de la Alcazaba, que funcionaría a modo de península, descendiendo suavemente hacia el mar; y otro menos pronunciado en dirección al paleoestuario del río, separados ambos por una vaguada coincidente con el trazado de la actual calle Alcazabilla (Recio 1989). En su día, se propuso una ocupación de la colina de la Alcazaba en el siglo VIII a.C., a partir del hallazgo en superficie de fragmentos de platos de engobe rojo de borde estrecho (Arteaga 1987: 213-214). Esta cronología, aportada a partir de un número mínimo de fragmentos, debe ser tomada con la correspondiente cautela (Ramon 2013: 29). Entre 1980 y 1985 se llevaron a cabo cuatro campañas de intervenciones arqueológicas en la ladera oeste de este promontorio, colindantes al extremo septentrional del graderío del teatro romano. Se constató una secuencia estratigráfica de ladera, sin evidencias constructivas, cuyos niveles más antiguos se fecharon entre el 600-580 a.C. (Gran-Aymerich 1991).

Respecto a las investigaciones realizadas en la más baja de estas dos elevaciones, hay que destacar los trabajos de excavación arqueológica llevados a cabo en el triángulo formado por los solares ubicados entre el Palacio de Buenavista, calle San Agustín y calle Císter. En el primero de los casos, las investigaciones fueron resultado de los trabajos de rehabilitación de este inmueble del siglo XVI para su actual uso como sede del Museo Picasso (Corrales 2006). La estratigrafía prerromana estaba muy alterada por la presencia de varios complejos destinados a la producción de salazones de época romana tardía (Mayorga 2006). No obstante, en determinados sectores se documentó una importante secuencia con más de $5 \mathrm{~m}$ de potencia desde el sustrato geológico. En los estratos más profundos se constató la presencia de varios momentos constructivos superpuestos identificados por tramos de muros rectos de mampostería (Fase I) e indicios de actividades metalúrgicas, que remontarían, según los investigadores, a momentos finales del siglo VII a.C. (Arancibia y Escalante 2006a: 48-50, fig. 9). Los materiales arqueológicos correspondientes a esta fase se han descrito de forma genérica. Se trata de cerámicas fenicias occidentales: vajilla de engobe rojo, formas abiertas y cerradas, junto a ánforas T-10121, así como un fragmento de un vaso griego que fue atribuido al Wild goat style -la única pieza publicada con ilustración correspondiente a los contextos más antiguos- (Arancibia y Escalante 2006a: 48, fig. 7) e interpretado recientemente como parte de un dino de taller de Quíos vinculado al Grand Style, fechado sobre el 600 a.C. (García 2018: 32-33). A esta misma fase se asoció un tramo de un potente muro, identificado parcialmente en los trabajos de seguimiento del proceso de cimentación, 
y que se ha propuesto que pudo formar parte de una primera cerca de la ciudad fenicia (Arancibia y Escalante 2006b: 356). Precisamente en este solar se han detectado restos de una vivienda fechada en la primera mitad del siglo VI a.C. (Escalante y Aguilar 2006a: 50- 51, fig. 10), amortizada por una compleja muralla con diversas fases constructivas, inmediatamente posterior (Suárez et al. 2007: 219-221).

En un solar contiguo, calle Císter 3 y San Agustín 4, una excavación con una amplia secuencia arqueológica ha proporcionado interesantes datos correspondientes al periodo fenicio-púnico. Se ha propuesto que el inicio de la secuencia arrancaría en momentos avanzados del siglo VII a.C. A una primera fase corresponden una serie de hoyos y estructuras, mal conservadas, que se han asociado con posibles indicios de actividades artesanales (Arancibia y Escalante 2006b: 344). Junto estos restos de construcciones, mal conocidas, se dispuso un inmueble con una estancia con suelo de arcilla coloreada en rojo en la que se instaló un altar del tipo del "piel de toro", y otra sala paralela con acceso pavimentado de conchas, a las que se accedía desde un pequeño patio o espacio abierto rodeado de una tapia. Estas construcciones, identificadas con el primer santuario fenicio de Malaka (Arancibia y Mora 2018: 356363), fueron amortizadas por la mencionada muralla del siglo VI a.C.

El sondeo del colegio de San Agustín fue realizado en 1986 (Recio 1989: 36) y su aportación básica fue la constatación, por primera vez, de la existencia de restos arquitectónicos fenicios en la ciudad. Dentro de la secuencia prerromana se pudieron distinguir dos fases, ambas del siglo VI a.C. La primera corresponde a una serie de estructuras que apoyaban sobre el firme de esquisto, colmatadas por depósitos con abundantes cerámicas fenicias y algunas importaciones griegas y etruscas. El conjunto se fechó en la primera mitad de dicha centuria y las estructuras se interpretaron como de carácter doméstico. La práctica antigua de actividades metalúrgicas en la zona se hizo evidente por la presencia de escorias y toberas. Estos restos aparecían a su vez amortizados por la muralla conocida en el Palacio de Buenavista y en el vecino solar de Císter.

\section{CONCLUSIONES}

Si atendemos al poblamiento de inicios de la Edad del Hierro en la bahía de Málaga, no puede desligarse la fundación fenicia de Malaka de un contexto colonial, preexistente y cercano, localizado en la desembocadura del río Guadalhorce, que queda tan solo a una distancia de poco más de $6 \mathrm{~km}$ en línea recta al oeste de la ciudad. En este ámbito, la excavación parcial de la Rebanadilla ha modificado bastante nuestra visión de la ocupación fenicia en el territorio, cuyo inicio podría retrotraerse a momentos de la segunda mitad del siglo IX a.C. (García 2016: 125). Por otro lado, el vecino establecimiento del Cerro del Villar precisa de más excavaciones y de la publicación de una serie de áreas investigadas, a los efectos de establecer no solo la caracterización de sus diversos sectores, sino también su secuencia cronológica, junto con la verificación de posibles hiatos planteados en ocasiones -según se desprende del estudio del corte 5 (Aubet 2018: 339-342)- y un tanto diluidos en otros casos (Delgado 2011). El tema de la secuencia cronoestratigráfica entre los enclaves del Cerro del Villar y de Malaka ha sido objeto de discusión, planteándose la posibilidad de una sustitución, a partir de los inicios del siglo VI a.C., del primero por el segundo (Aubet 1994: 295, entre otros trabajos).

Los datos aportados por el estudio de los niveles más profundos de la secuencia estratigráfica obtenida en la excavación del antiguo edificio de Correos, objeto de este trabajo, y su encaje en la cronología del poblamiento fenicio de la margen izquierda del río Guadalmedina, cuentan con un problema de partida: como se ha avanzado, el grueso de los materiales cerámicos recuperados en las recientes intervenciones arqueológicas de referencia, que deben sustentar el anclaje temporal con las estratigrafías antes descritas y su comparación con la que nos ocupa, está pendiente de su publicación definitiva. En este sentido, resulta fundamental ajustar las cronologías de contextos singulares previsiblemente coetáneos o poco posteriores, como el santuario de calle Císter, amortizado por la muralla púnica en momentos avanzados de la primera mitad del siglo VI a.C. Esto permitirá afinar su relación con el sitio objeto de estudio en estas páginas y ahondar en el conocimiento de esta primera fase de ocupación de Malaka.

De este modo, si se admite que Malaka ya existía, al menos, antes del 625 a.C., como se ha intentado demostrar en el presente trabajo, habría que insistir en la caracterización del poblamiento fenicio en la bahía de Málaga alrededor del tercer cuarto del siglo VII a.C., haciendo hincapié en el papel desempañado por el Cerro del Villar en estos momentos. En el estado actual de la investigación, la necesidad de nuevas excavaciones $\mathrm{y}$, desde luego, de la publicación detallada de contextos todavía inéditos, hace sumamente arriesgado cualquier tipo de hipótesis en este sentido. 
Junto a sus valiosas indicaciones cronológicas, la excavación del antiguo edificio de Correos ha aportado datos de interés topográfico para el conocimiento del primer asentamiento fenicio en la ciudad. La evidencia de muros de cierta entidad confirma la existencia de construcciones arcaicas inmediatas a la primera línea de costa. Sin embargo, cabe observar que se trata de la costa exterior, desprotegida frente a vientos y oleaje, hecho que obliga a excluir este punto como lugar portuario, más aún contándose en esta época con el amplio estuario del Guadalmedina, mucho menos sedimentado $\mathrm{y}$, evidentemente, mucho más protegido (Mora y Arancibia 2010: 821,García 2017). Esta circunstancia no es contraria, sin embargo, a su potencial uso como sitio de amarre ocasional para embarcaciones menores.

Por ello, la naturaleza de las construcciones identificadas en Correos, máxime considerando la escasez de restos documentados, resulta difícil de interpretar. Una posibilidad es que formaran parte de un sistema de hábitat escalonado y en este caso, se podría barajar la extensión del primer asentamiento fenicio a la parte baja de la ladera meridional de la Alcazaba. Cabe también recordar que, de haber existido una cerca fenicia del siglo VII a.C., como se ha propuesto en las excavaciones del Palacio de Buenavista (Arancibia y Escalante 2006b: 356), tendría que haber contado con un cierre por el extremo sureste del asentamiento desde un punto de vista estratégico, por lo que la posibilidad de vincular estas construcciones a parte de un sistema defensivo tampoco puede ser totalmente descartada, aunque supone otros problemas a la hora de interpretar el urbanismo del primer asentamiento.

En suma, puede afirmarse que el futuro de la investigación sobre la arqueología fenicia malacitana pasa por un estudio sistemático y contextualizado de todos los datos disponibles, potenciando su estudio y publicación de excavaciones antiguas, como necesario contrapeso a los desarrollos teóricos propuestos.

\section{Agradecimientos}

Agradecemos a José Luis Vera y María del Carmen Lozano las referencias básicas de la clasificación de los restos malacológicos, así como a Eduardo García Alfonso (jefe del Departamento de Difusión del Museo de Málaga, Junta de Andalucía) el estudio de los fragmentos de ánfora griega, objeto de una futura publicación específica por parte de este investigador.

Esta publicación forma parte de los resultados del proyecto de investigación I+D (HAR2015-68669-P), financiado por el Gobierno de España.

\section{BIBLIOGRAFÍA}

Almagro-Gorbea, M. (2013): "La 'Tumba de Melqart' del Herákleion de Gadir". Madrider Mitteilungen 54: 159-202.

Arancibia, A.; Escalante, M. M. (2006a): "La Málaga fenicio-púnica a la luz de los últimos hallazgos". Mainake XXVIII: 333-360.

Arancibia, A.; Escalante, M. M. (2006b): “Génesis y consolidación de la ciudad de Malaka". Memoria Arqueológica del Museo Picasso Málaga: desde los orígenes hasta el siglo V d.C.: 41-78. Málaga, Museo Picasso-Málaga.

Arancibia, A.; Galindo, L.; Juzgado, M.; Dumas, M.; Sánchez, V. M. (2011): "Aportaciones de las últimas intervenciones a la arqueología fenicia de la Bahía de Málaga”, en M. Álvarez (ed.), Fenicios en Tartesos: nuevas perspectivas. BAR International Series 2245: 129-149. Oxford, Archaeopress.

Arancibia, A.; Fernández, L.E. (2012): "El periodo fenicio arcaico en la Bahía de Málaga”, en E. García (ed.), Diez años de arqueología fenicia en la provincia de Málaga (2001-2010). Monografías-Arqueología: 49-66. Sevilla, Junta de Andalucía.

Arancibia, A.; Mora, B. (2018): "Malaka before the Polis: a Colonial Emporium of the 7thC. BC Inheritor of the Archaic Phoenician Settlement on the Guadalhorce River Mouth", en M. Botto (ed.), De Huelva a Malaka. Los fenicios en Andalucía a la luz de los descubrimientos más recientes. Collezioni di Studi Fenici 47: 351369. Roma, Consiglio Nazionale delle Ricerche.

Arnold, F.; Marzoli, D. (2009): "Toscanos, Morro de Mezquitilla und Las Chorreras im 8. Und 7. Jh. v. Chr: Siedlungsstruktur und Wohnhaustypologie", en S. Helas, D. Marzoli (eds.), Phönizisches und punisches Städtewesen. Iberia Archaeologica 13: 437-460. Mainz, P. von Zabern.

Arribas, A.; Wilkins, J. (1971): "La necrópolis fenicia del Cortijo de Las Sombras (Frigiliana, Málaga)". Pyrenae 5: 185-244.

Arteaga, O. (1978): "Problemática general sobre la iberización en Andalucía Oriental y en el Sudeste de la Península", en Simposi Internacional: El origens del món ibèric (Barcelona, Empúries, 1977). Ampurias 38-40: 23-60.

Aubet, M. E. (1994): Tiro y las colonias fenicias de Occidente, Edición ampliada y puesta al día. Barcelona, Crítica.

Aubet, M. E. (1997): "Un lugar de mercado en el Cerro del Villar", en M. E. Aubet (coord.), Los fenicios en Málaga: 197-221. Málaga, Universidad de Málaga. 
Aubet, M. E. (1999a): "La secuencia arqueo-ecológica del Cerro del Villar", en A. González (ed.), La cerámica fenicia de occidente. Centros de producción $y$ áreas de comercio. Actas del I Seminario Internacional sobre temas fenicios: 41-68. Guardamar del Segura (1997), Alicante, Instituto de Cultura Juan Gil-Albert.

Aubet, M. E. (1999b): "La estratigrafía del corte 5", en M. E. Aubet, P. Carmona, E. Curià, A. Delgado, A. Ferrnández Cantos y M. Párraga, Cerro del Villar I. El asentamiento fenicio en la desembocadura del río Guadalhorce y su interacción con el hinterland, Arqueología. Monografías: 76-127. Sevilla, Junta de Andalucía.

Aubet, M. E. (2018): "La colonia fenicia del Cerro del Villar", en M. Botto (ed.), De Huelva a Malaka. Los fenicios en Andalucía a la luz de los descubrimientos más recientes, Collezioni di Studi Fenici 48: 325-349. Roma, Consiglio Nazionale delle Ricerche.

Aubet, M. E.; Maass-Lindemann, G.; Schubart, H. (1979): "Chorreras. Un establecimiento fenicio al este de la desembocadura del río Algarrobo". Noticiario Arqueológico Hispánico 6: 89-138.

Aubet, M. E.; Carmona, P.; Curià, E.; Delgado, A.; Fernández, A.; Párraga, M. (1999): Cerro del Villar - I. El asentamiento fenicio en la desembocadura del rio Guadalhorce y su interacción con el hinterland, Arqueología. Monografías. Sevilla, Junta de Andalucía.

Barresi, P. (2007): Metrologia púnica. Lugano, Athenaion.

Cabrera, P. (1994): “Importaciones arcaicas del Cerro del Villar (Guadalhorce, Málaga)", en P. Cabrera, E. Sanmartí, R. Olmos Romera (eds.), Iberos y griegos: Lecturas desde la diversidad. Simposio Internacional. Ampurias (1991). Huelva Arqueológica XIII: 97-121.

Chacón, C.; Salvago, L. (2005): “Actividad arqueológica en la antigua Casa de Correos y Telégrafos. Integración de los restos excavados en la sede de la Universidad de Málaga (1998-2002)". Anuario Arqueológico de Andalucía 2002, III, 2: 18-28. Sevilla, Junta de Andalucía.

Campo, M.; Mora, B. (1995): Las monedas de Malaca. Madrid, Fábrica Nacional de Moneda y TimbreMuseo Casa de la Moneda.

Cardell, C. 1999: “Anexo V. Arqueometría de las cerámicas fenicias”, en M. E. Aubet, P. Carmona, E. Curià, A. Delgado, A. Ferrnández Cantos y M. Párraga, Cerro del Villar - I. El asentamiento fenicio en la desembocadura del río Guadalhorce y su interacción con el hinterland. Arqueología-Monografías: 1-23. Sevilla, Junta de Andalucía.

Cisneros, M. I.; Suárez, J.; Mayorga, J.; Escalante, M. M. (2001): "Cerámicas griegas arcaicas en la Bahía de Málaga”, en P. Cabrera, M. Santos (coords.), Ceràmiques jònies d'època arcaica: centres de producció i comercialització al Mediterrani occidental: actes de la Taula Rodona:189-206. Empúries (1999), Empúries, Museu d‘Arqueologia de Catalunya.

$\mathrm{CNH}=$ Villaronga, L. (1994): Corpus Nummum Hispaniae ante Augustiaetatem. Madrid, J. A. Herrero.

Corrales, M. (2006): “Introducción”, Memoria Arqueológica del Museo Picasso Málaga: desde los orígenes hasta el siglo V d.C.: 14-18. Málaga, Museo Picasso-Málaga.

Corrales, M.; Corrales, M. P. (2012): "Malaca: de los textos literarios a la evidencia arqueológica", en J. Beltrán Fortes, O. Rodríguez Gutiérrez (coords.), Hispaniae urbes. Investigaciones arqueológicas en ciudades históricas. Serie Historia y Geografía 203: 363-402. Sevilla, Universidad de Sevilla.

Curià, E.; Delgado, A.; Fernández, A.; Párraga, M. (1999): "El taller alfarero de principios del siglo VI a.C. 2. Estudio de los materiales cerámicos”, en M. E. Aubet, P. Carmona, E. Curià, A. Delgado, A. Ferrnández Cantos y M. Párraga, Cerro del Villar - I. El asentamiento fenicio en la desembocadura del rio Guadalhorce y su interacción con el hinterland: 157-277 Arqueología- Monografías. Sevilla, Junta de Andalucía.

Delgado, A. (2005): "Multiculturalidad y género en las colonias fenicias de la Andalucía mediterránea: un análisis contextual de las cerámicas a mano del Cerro del Villar (Málaga)", en V Congresso Internazionale di Studi Fenici e Punici III: 1249-1260. Marsala - Palermo (2000), Palermo, Università degli Studi.

Delgado, A. (2011): "La producción de cerámica fenicia en el extremo Occidente: hornos de alfar, talleres e industrias domésticas en los enclaves coloniales de la Andalucía mediterránea (siglos VIII-VI a.C.)", en Yoserim: la producción alfarera feniciopúnica en Occidente. Treballs del Museu Arqueològic d'Eivissa i Formentera 66: 9-48. Eivissa. Museo Arqueológico de Ibiza y Formentera.

Díaz, M.J. (2011): “Intervención arqueológica preventiva en la parcela UE 3, 4.31 del PERI TrinidadPerchel (Málaga, Barrio de la Trinidad)". Anuario Arqueológico de Andalucía 2004, III.2: 3498-3508. Sevilla, Junta de Andalucía. 
Docter, R. F. (1997): Archaische Amphoren aus Karthago und Toscanos. Fundspektrum und Formentwicklung ein Beitrag zur phönizischen Wirtschaftsgeschichte. Amsterdam, Proefschrift Universiteit van Amsterdam.

Fernández, L. E.; Suárez, J.; Navarro, I.; Cisneros, M. I.; Mayorga, J.; Rambla, A.; Arancibia, A.; Escalante, M. M. (1997): "Un poblado indígena del siglo VIII a.C. en la bahía de Málaga. La intervención de urgencia en la plaza de San Pablo", en M.E. Aubet (coord.), Los fenicios en Málaga: 215-251. Málaga, Universidad de Málaga.

Ferrando, M.; Íñiguez, M.C. (2011): “Resultados de la intervención efectuada en la calle de San Pablo $\mathrm{n}^{\mathrm{o}}$ 19, en Málaga". Anuario Arqueológico de Andalucía 2004, III.2: 3449-3457. Sevilla, Junta de Andalucía.

Florido, D.D.; Navarrete, V.; Ramírez, J.D.; Ruiz, N.; Sabastro, M.A. (2012): "Un hipogeo con forma de piel de toro a orillas del Guadalmedina. Málaga", en E. García (ed.), Diez años de arqueología fenicia en la provincia de Málaga (2001-2010): 121-136. Monografías Arqueología. Sevilla, Junta de Andalucía.

García, A.; Prados, F. (2014): "La presencia fenicia en la Península Ibérica: el Cabezo Pequeño del Estaño (Guardamar del Segura, Alicante)". Trabajos de Prehistoria 71.1: 113-133. doi: <https://doi. org/10.3989/tp.2014.12127>.

García, E. (1994): “Los Castillejos de Teba (Málaga). Campaña de 1993. Estratigrafía de los siglos VIIIVII a.C.”. Mainake XV-XVI: 45-83.

García, E. (2007): En la orilla de Tartessos. Indígenas y fenicios en las tierras malagueñas. Siglos XI-VI a. C. Málaga, Fundación Málaga.

García, E. (2016): “Las primeras importaciones griegas en Occidente y la cronología de la cerámica geométrica hacia un nuevo paradigma (I)". Menga. Revista de Prehistoria de Andalucía: 101-132.

García, E. (2017): “Aproximación a los fondeaderos fenicios de la bahía de Málaga y su evolución: paleografía y arqueología”, en M. Martínez, J.M. García, J. Blánquez, A. Iniesta (eds.), Mazarrón II. Contacto, viabilidad y perspectivas del barco $B-2$ de la bahía de Mazarrón. Homenaje a Julio Mas García: 341384. Mazarrón, Universidad Autónoma de Madrid.

García, A. (2018): "Málaka en los siglos VII-VI a.C. Los orígenes de una ciudad-estado fenicia occidental", en D. García, S. López, E. García (eds.), La tumba del guerrero. Un enterramiento excepcional en la Málaga fenicia del siglo VI a.C.: 2474. Arqueología Monografías. Sevilla, Junta de Andalucía.
Gener, J. Mª Navarro M.-Á.; Pajuelo, J.-M.; Torres, M.; López, E. (2014): "Arquitectura y urbanismo de la Gadir fenicia: el yacimiento del "Teatro Cómico" de Cádiz", en M. Botto (ed.), Los fenicios en la Bahía de Cádiz. Nuevas investigaciones, Collezione di Studi Fenici 46: 14-50. Pisa - Roma, Fabrizio Serra.

González, A. (2011a): "Las ánforas (Tipos 1 a 6)", en A. González (coord. y ed.), La Fonteta. Excavaciones de 1996-2002 en la colonia fenicia de la actual desembocadura del río Segura (Guardamar del Segura, Alicante) 1. Seminarios Internacionales sobre Temas Fenicios: 291-374. Alicante, Universidad de Alicante.

González, A. (2011b): “Ollas monoansadas (Tipo 8)”, en A. González (coord. y ed.), La Fonteta. Excavaciones de 1996-2002 en la colonia fenicia de la actual desembocadura del río Segura (Guardamar del Segura, Alicante) 1. Seminarios Internacionales sobre Temas Fenicios: 395-416. Alicante, Universidad de Alicante.

González, A. (2011c): "Platos de ala (Tipo 18)", en González, A. (coord. y ed.) La Fonteta. Excavaciones de 1996-2002 en la colonia fenicia de la actual desembocadura del río Segura (Guardamar del Segura, Alicante) 1. Seminarios Internacionales sobre Temas Fenicios: 573-657. Alicante, Universidad de Alicante.

González, A. (2014 a): "La cerámica a torno: Tipos 12 a 21 ", en A. González (coord. y ed.), La Fonteta-2. Estudio de los materiales arqueológicos hallados en la colonia fenicia de la actual desembocadura del río Segura (Guardamar, Alicante) 2, 1. Seminarios Internacionales Sobre Temas Fenicios: 426552. Alicante, Universidad de Alicante.

González, A. (2014 b): "La cerámica a torno: Tipos 2332, 35-42 y 44-48”, en A. González (coord. y ed.), La Fonteta-2. Estudio de los materiales arqueológicos hallados en la colonia fenicia de la actual desembocadura del río Segura (Guardamar, Alicante) 2, 2. Seminarios Internacionales Sobre Temas Fenicios: 573-671. Alicante, Universidad de Alicante.

Gran-Aymerich, J. M. J. (1991): Málaga phénicienne et punique. Recherches franco-espagnoles 19811988. Paris, Recherche sur les Civilisations.

Hoffmann, G. (1988): Holozänstratigraphie und Küstenlinienver-lagerung an der andalusischen Mittelmeerküste. Fachbereich Geowissenschaften der Universität Bremen 2. Bremen, Universität Bremen.

Jodin, A. (1966): Mogador, comptoir phénicien du Maroc atlantique. Tanger, Éditions marocaines et internationales. 
López, F.; Habibi, M. (2001): “Le comptoir phénicien de Mogador: Approche chronologique et céramique à engobe rouge", en Actes des lères Journées Nationales d'Archéologie et du Patrimoine: 53-63. Rabat (1998), Rabat, Société Marocaine d'Archéologie et du Patrimoine.

Maass-Lindemann, G. (1982): Toscanos. Die Westpönikische Niederlassung an der Mündung des Rio de Vélez. Lieferung 3. Grabunpskampagne 1971 und die impordatierte Westphönikische Grabkeramik des 7/6 J.H.S V. CHR. Madrider Forschungen 6. Berlin, P. von Zabern.

Maass-Lindemann, G. (1988): "Alarcon. Vorbericht über die Funde aus der Grabungskampagne 1984", en O. Arteaga Matute, C. Briese, R. Bahnemann (eds.), Forschungen zur Archäologie und Geologie im Raum von Torre del Mar, 1983/84. Madrider Beitrage 14: 189-197. Mainz, P. von Zabern.

Martín, E.; Recio, A. (2012): "Yacimientos fenicios en la costa de Vélez-Málaga. Nuevas intervenciones arqueológicas", en E. García (ed.), Diez años de arqueología fenicia en la provincia de Málaga (20012010): 207-245. Monografías Arqueología. Sevilla, Junta de Andalucía.

Martín, E.; Ramírez, J. de D.; Recio, A. (2006): “Producción alfarera fenicio-púnica en la costa de Vélez-Málaga (siglos VIII-V a.C.)". Mainake XXVIII: 257-287.

Martín, E.; Ramírez, J. de D.; Ruescas, V.; Recio, Á. (2006): "Necrópolis fenicias de los siglos VIII-VII a.C. en la desembocadura del río de Vélez". Mainake XXVIII: 303-331.

Martín, J.A. (2010): "El urbanismo en la colonia fenicia de Malaca". Byrsa 17-18: 73-90.

Martín, J.A.; Hirado, R. (2018): La colonia fenicia de Suel (Fuengirola, Málaga). Análisis histórico y arqueológico. Fuengirola, Ayuntamiento de Fuengirola.

Maya, R.; Jurado, G.; Gener, J. Mª; López, E.; Torres, M.; Zamora, A. (2014): "Nuevos datos sobre la ubicación del Kronion de Gadir: las evidencias de época fenicia arcaica", en M. Botto, M. (ed.), Los fenicios en la Bahía de Cádiz. Nuevas investigaciones. Collezione di Studi Fenici 46: 156-180 Pisa Roma, Fabrizio Serra.

Mayorga, J. (2006): "El periodo romano en el Museo de Málaga", en Memoria Arqueológica del Museo Picasso Málaga: desde los orígenes hasta el siglo $\mathrm{V}$ d.C.: 93-116. Málaga, Museo Picasso-Málaga.

Melero, F. (2008): "Nuevas aportaciones para el estudio del Bronce Final de San Pablo (Málaga). La secuencia de C/ Tiro 9-11, esquina Zamorano". Mainake XXX: 355-377.

Melero, F. (2009): "Descubrimiento de una nueva secuencia fenicia completa en los solares $\mathrm{n}^{\circ} 9$ y 11 de la C/Tiro, esq. Zamorano (Barrio de la Trinidad, Málaga)". Anuario Arqueológico de Andalucía 2004, 1: 2430-2440. Sevilla, Junta de Andalucía.

Molina, F.; Huertas, C. (1985): Almuñecar en la antigüedad. La necrópolis fenicio-púnica de Puente de Noy II. Granada, Caja Provincial de Ahorros de Granada.

Molina, F.; Rodríguez, A.; Buendía, A. (1984): “Excavaciones en el casco antiguo de Almuñecar", en F. Molina Fajardo (ed.), Almuñecar Arqueología e Historia II: 121-183. Granada, Caja de Ahorros Provincial de Granada.

Montanero, D. (2014): "Arquitectura doméstica fenicio-púnica en Sicilia y Cerdeña (siglos VIII-III a.C.)", en Arquitectura urbana y espacio doméstico en las sociedades fenicio-púnicas. XXVIII Jornadas de arqueología fenicio-púnica: 41-110. Eivissa (2013), Eivissa, Museu Arqueològic d'Eivissa i Formentera.

Mora, B.; Arancibia, A. (2010): “La bahía de Málaga en los períodos púnico y romano-republicano: viejos problemas y nuevos datos". Mainake XXXII: 813-836.

Mora, B.; Arancibia, A. (2018): "Malaka en los siglos VI-V a.C.: la consolidación de una polis fenicio-púnica en el sur de la Península Ibérica". Archivo de Prehistoria Levantina 32: 117-134. IRI <http://mupreva.org/pub/1019/es>.

Mora, B. (2011): "The Imaginary Far West and South Iberian and North African Punic Coins", en A. Dowler, E.R. Galvin (eds.), Money, Trade and Trade Routes in Pre-Islamic North Africa: 21-32. Londres, The British Museum.

Olmedo, M. (2006): “Los orígenes del Parque de Málaga”. Péndulo. Revista de Humanidades 7: 174-184.

Orsingher, A. (2010): "Le oil bottles fenicie: analisi dei contesti e considerazioni crono-tipologiche". DOI: $<$ https://doi.org/10.1400/157169>. Sardinia, Corsica et Baleares Antiquae 8: 37-69.

Ramon, J. (1982): "Cuestiones de comercio arcaico: frascos de aceite perfumado en el Mediterráneo central y occidental". Ampurias 44: 17-41.

Ramon, J. (1992): "La colonización arcaica de Ibiza. Mecánica y proceso”, en G. Roselló Bordoy (coord.), La Prehistòria de les Illes de la Mediterrània Occidental. X Jornades d'Estudis Històrics 
Locals: 453-478. Palma de Mallorca (1991), Palma de Mallorca, Institut d'Estudis Baleàrics.

Ramon, J. (1994): "El nacimiento de la ciudad fenicia de la bahía de Ibiza", en A. González Blanco et al. (coords.), El Mundo Púnico. Historia, Sociedad y Cultura. Coloquios de Cartagena. Cartagena, nov. 1990). Biblioteca Básica Murciana, Extra 4: 325 368. Murcia, Editorial Regional de Murcia.

Ramon, J. (1995): Las ánforas fenicio-púnicas del Mediterráneo Central y Occidental. Instrumenta 2. Barcelona, Universidad de Barcelona.

Ramon, J. (1999): "La cerámica fenicia a torno de sa Caleta", en A. González Prats (ed.), La cerámica fenicia de occidente. Centros de producción y áreas de comercio. Actas del I Seminario Internacional sobre temas fenicios: 149-214. Guardamar del Segura (1997), Alicante, Instituto de Cultura Juan GilAlbert.

Ramon, J. (2007): Excavaciones arqueológicas en el asentamiento fenicio de sa Caleta, Cuadernos de Arqueología Mediterránea 16. Barcelona, Publicaciones del Laboratorio de Arqueología.

Ramon, J. (2010): "La cerámica fenicia del Mediterráneo extremo-occidental y del Atlántico (s. VIII - 1r 1/3 del VI aC). Problemas y perspectivas actuales", en L. Nigro (ed.), Motya and the Phoenician ceramic repertoire between the Levant and the West 9th6th century BC: Proceedings of the International Conference: 211-253. Roma (2010), Roma, Missione Archeologica a Mozia.

Ramon, J. (2013): "Les villes phéniciennes puniques de l'extrême occident méditerranéen et atlantique", en Urbanisme et architecture en Méditerranée antique et médiévale à travers les sources archéologiques et littéraires. Actes du 2ème Colloque International: 15-49. Túnez (2011), Túnez, Institut Supérieur des Sciences Humaines.

Recio, A. (1989): "Consideraciones acerca del urbanismo de Málaga fenicio-púnica”. Mainake X: 75-82.

Recio, A. (1989): La cerámica fenicio-púnica, griega y etrusca del sondeo de San Agustín. Monografías 3. Málaga, Diputación Provincial.

Rodríguez de Berlanga, M. (2001): “Conjeturas topográficas”. Malaca VI: 217-237. Málaga, Ayuntamiento de Málaga (reed.).

Rufete, P. (1989): “Las cerámicas con engobe rojo de Huelva”. Huelva Arqueológica X-XI, 3: 9-40.

Rufete, P. (1989): "La cerámica con barniz rojo de Huelva", en Ma . E. Aubet (ed.), Tartessos. Arqueología protohistórica del bajo Guadalquivir: 375 394. Sabadell, Ausa.
Ruiz, D.; Pérez, C. (1995): El poblado fenicio del Castillo de Doña Blanca (El Puerto de Santa María, Cádiz). Biblioteca de Temas Portuenses 5. El Puerto de Santa María, Ayuntamiento de El Puerto de Santa María.

Sánchez, V. M.; Galindo, L.; Juzgado, M.; Dumas M. (2011): "La desembocadura del Guadalhorce en los siglos IX y VIII a. C. y su relación con el Mediterráneo", en J. C. Domínguez (ed.), Gadir y el Círculo del Estrecho revisados. Propuestas de la arqueología desde un enfoque social: 185-200. Cádiz, Universidad de Cádiz.

Sánchez V. M.; Galindo, L.; Juzgado, M.; Dumas, M. (2012): "El asentamiento fenicio de la Rebanadilla a finales del siglo IX a.C.”, en E. García (ed.), Diez años de Arqueología Fenicia en la provincia de Málaga (2001-2010): 67-85. Monografías Arqueología. Sevilla, Junta de Andalucía.

Sánchez, V.M.; Galindo, J.L.; Juzgado, M.; Belmonte, J.A. (2018): "La Rebanadilla, santuario litoral fenicio en el sur de la Península Ibérica", en M. Botto (ed.), De Huelva a Malaka. Los fenicios en Andalucía a la luz de los descubrimientos más reciente. Collezione di Studi Fenici 48: 305-324. Roma, Consiglio Nazionale delle Ricerche.

Santamaría, J. A.; Suárez, J.; Ramon, J. (2012): “Taralpe Alto (Alhaurín de La Torre, Málaga). Un nuevo asentamiento de la Edad del Hierro en el entorno de la cuenca baja del río Guadalhorce", en E. García (ed.), Diez años de arqueología fenicia en la provincia de Málaga (2001-2010): 193206. Monografías Arqueología. Sevilla, Junta de Andalucía.

Schubart, H. (1976): "Westphönizische Teller". Rivista di Studi Fenici IV. 2:179-196.

Schubart, H.; Maass-Lindemann, G. (1984): “Toscanos: el asentamiento fenicio occidental en la desembocadura del río de Vélez (excavaciones de 1971)". Noticiario Arqueológico Hispánico 18: 41-205.

Schubart, H.; Maass-Lindemann, G. (1995): "Las excavaciones en la Necrópolis de Jardín (Vélez-Málaga, Málaga)".Cuadernos de Arqueología Mediterránea 1: 57-64.

Schubart, H.; Niemeyer, H. G. (1976): Trayamar. Los hipogeos fenicios y el asentamiento en la desembocadura del río Algarrobo. Excavaciones Arqueológicas en España 90. Madrid, Ministerio de Educación y Ciencia.

Schubart, H.; Niemeyer, H. G.; Pellicer, M. (1969): Toscanos. La factoría paleopúnica en la desembocadura del río Vélez, Excavaciones de 1964. 
Excavaciones Arqueológicas en España 66. Madrid, Ministerio de Educación y Ciencia.

Serrano, E.; Rodríguez, P. (2009): "El mosaico de Bellerofonte de la villa de Puerta Oscura". Jábega 100: 48-54.

Suárez, J.; Cisneros, M. I. (1999): "La entrada de los territorios de Benalmádena en la Historia", en A. Palomo Laburu et al. (eds.), Una historia de Benalmádena: 99-126. Benalmádena, Delegación de Cultura.

Suárez, J.; Escalante, M. del M.; Cisneros, M. I.; Mayorga, J.; Fernández, L. E. (2007): “Territorio y urbanismo fenicio-púnico en la bahía de Málaga. Siglos VIII-V a.C.”, en J. L. López Castro (ed.), Las ciudades fenicio-púnicas en el Mediterráneo occidental: 209-232. Almería, Universidad de Almería.

Torres, M.; López, E.; Gener, J. Ma; Navarro, M. Á.; Pajuelo, J. M.; Maya, R.; Jurado, G. (2014): "El material cerámico de los contextos fenicios del "Teatro
Cómico" de Cádiz: un análisis preliminar", en M. Botto (ed.), Los Fenicios en La Bahía de Cádiz. Nuevas investigaciones. Collezione di Studi Fenici 46: 51-82. Pisa - Roma, Fabrizio Serra.

Ulreich, H.; Negrete, M. A.; Puch, E.; Perdigones, L. (1990): “Cerro del Prado. Die ausgrabungen 1989 im schutthang der phönizischen ansiedlung an der Guadarranque-mundung". Madrider Mitteilungen 31: 194-250.

Villada, F.; Ramon, J.; Suárez, J. (2010): El asentamiento protohistórico de Ceuta. Indígenas y fenicios en la orilla norteafricana del Estrecho de Gibraltar. Ceuta, Archivo General de Ceuta.

Vuillemot, G. (1955): "La nécropole punique du Phare dans l'île de Rachgoun (Oran)". Libyca (Arch. Ep.) III: 7-76.

Vuillemot, G. (1965): Reconnaissances aux échelles puniques d'Oranie. Autun, Musée Rolin. 
